\title{
Clinicopathological characteristics and survival outcomes of younger patients with gastric cancer: a systematic review and meta-analysis
}

\author{
Penghui Niu ${ }^{1 \#}$, Lulu Zhao ${ }^{1 \#}$, Rui Ling ${ }^{2 \#}$, Dongbing Zhao ${ }^{1}$, Yingtai Chen ${ }^{1}$ \\ ${ }^{1}$ National Cancer Center/National Clinical Research Center for Cancer/Cancer Hospital, Chinese Academy of Medical Sciences, and Peking Union \\ Medical College, Beijing, China; ${ }^{2}$ Department of Microbiology and Immunology, Georgetown University Medical Center, Washington, DC, USA \\ Contributions: (I) Conception and design: All authors; (II) Administrative support: All authors; (III) Provision of study materials or patients: P Niu, L \\ Zhao, R Ling; (IV) Collection and assembly of data: P Niu, L Zhao; (V) Data analysis and interpretation: L Zhao, R Ling; (VI) Manuscript writing: \\ All authors; (VII) Final approval of manuscript: All authors. \\ \#These authors contributed equally to this work. \\ Correspondence to: Yingtai Chen. National Cancer Center/National Clinical Research Center for Cancer/Cancer Hospital, Chinese Academy of \\ Medical Sciences and Peking Union Medical College, 17 Panjiayuan Nanli, Beijing, China. Email: yingtaichen@126.com.
}

\begin{abstract}
Background: Survival outcomes of gastric cancer in younger patients have been reported in several studies with controversial results. This systematic review and meta-analysis investigated the clinicopathological characteristics, postoperative complications, and survival outcomes between younger and older patients.
\end{abstract}

Methods: We systematically reviewed clinical researches from PubMed, The Cochrane Library, Embase, and Web of science published up to December 2019. The effect size for the included studies was estimated with the odds ratio (OR). Heterogeneity was investigated using the $\chi^{2}$ test and $\mathrm{I}^{2}$ test, while sensitivity analyses were performed to identify the source of substantial heterogeneity.

Results: A total of 25 clinical studies involving 81,188 gastric cancer patients were included in this metaanalysis, of which one was a prospective study. Younger patients were more likely to be females, pTNM stage IV and peritoneal metastasis. The incidence of postoperative complications, lymph node metastasis, as well as hepatic metastasis of younger patients was significantly lower than that of the older. There was no statistical difference in overall survival (OS) between the younger and older patients with gastric cancer. After stratification for patients with gastrectomy, however, younger patients were associated with a better 5 -year OS relative to older patients.

Conclusions: In conclusion, younger patients with gastric cancer were more often diagnosed as poorly differentiation and later pTNM tumor stage. However, younger cancer patients following gastrectomy had a better OS rate than patients in older group. Future large-scale analyses are expected to confirm our findings.

Keywords: Gastric cancer; younger adult; clinicopathological characteristics; survival outcomes; meta-analysis

Submitted May 07, 2020. Accepted for publication Aug 21, 2020.

doi: $10.21037 /$ tcr-20-2024

View this article at: http://dx.doi.org/10.21037/tcr-20-2024

\section{Introduction}

Gastric cancer is an aggressive malignancy and remains the third leading cause of cancer-related death worldwide $(1,2)$. Although the overall incidence of gastric cancer showed a decline worldwide, younger cancer patients had increased obviously during the last decades (3). The growing incidence, as well as its aggressive biological behavior as reported $(4,5)$, has renewed interest in the surgery-based management of younger gastric cancer patients with a focus on therapeutic strategies. 
To date, the survival outcomes of younger patients were still controversial. Previous data reported that younger patients had worse survival rates than older (6-9), whereas several studies showed a similar prognosis (10-20). Some studies even expressed that younger patients were associated with improved survival outcomes (21-30). A significant reason for these inconsistent findings from published studies was the different age cutoffs on defining younger patients $(6,7,29,30)$. A published meta-analysis has reported improved 5 -year survival in the younger group. However, it was primarily limited to the small sample size and significant heterogeneity (31). Besides, there was currently no randomized clinical trial that targeted the issue.

As such, our study aimed to compare the clinicopathological characteristics, postoperative complications, as well as survival outcomes between younger and older patients with gastric cancer through systematic review and meta-analysis, thus providing evidence for the development of guiding strategies for younger gastric cancer patients. We present the following article in accordance with the PRISMA reporting checklist (available at http://dx.doi.org/10.21037/tcr-20-2024).

\section{Methods}

\section{Search strategy}

Clinical studies were systematically searched from PubMed, Web of Science, Embase, and The Cochrane Library. The following fields were used for the search: "gastric" or "stomach," "cancer" or "carcinoma" or "neoplasm" or "tumor," "young adult" or "younger" or "youth." These searches were limited to clinical articles published up to December 2019.

\section{Inclusion and exclusion criteria}

Studies met the following criteria were included: (I) researches compared gastric cancer in the younger group ( $\leq 40$ years of age) and older group ( $>40$ years of age); (II) analyses contained quantitative clinicopathological information; (III) researches involved at least one of the mentioned survival outcomes.

Studies were excluded from the analysis as follow: (I) publications were position papers, editorials, case reports, comments, or review articles; (II) literature duplication based on an author or center; (III) research data was inappropriate or cannot be extracted; (IV) studies lacked control group for meta-analysis.

\section{Data extraction}

Two independent reviewers extracted predesigned data from the included studies. The extracted information was as follows: Basic characteristics of the study, including authors, country, patient inclusion criteria, sample size, design as well as quality assessment; Clinicopathological characteristics of patients, including gender, tumor location, differentiation, Lauren type, Borrmann classification, pTNM stage, and therapeutic regimens (involving chemotherapy, total/subtotal gastrectomy, curative resection, and lymphadenectomy); Survival outcomes, including metastasis, recurrence, and the short or longterm survival rates on different clinical tumor stage. The stage of gastric cancer was based on the American Joint Committee on Cancer (AJCC) tumor, node, metastasis (TNM) staging system. Lymphadenectomy was divided into D1 to D4, depending on the primary tumor location and removal of each lymph node station (32). Gastrectomy was defined as patients received surgery with or without D2 lymphadenectomy, while curative gastrectomy was defined as resection with D2 lymphadenectomy and a negative margin. The disagreement was resolved through discussion among the reviewers.

\section{Quality assessment}

The quality of the included studies was evaluated using The Newcastle-Ottawa Quality Assessment Scale (NOS) (33). The NOS checklist consisted of three major categories (selection, comparability, and outcome) with a maximum of nine stars. Each included study achieving six or more number of stars was graded high quality. Any disagreement was discussed to reach a consensus.

\section{Statistical analysis}

We conducted the review and meta-analysis using Revman software, version 5.3 (Cochrane Collaboration, Oxford, United Kingdom). Categorical variables were analyzed by the odds ratio (OR), while the corresponding $95 \%$ confidence interval (CI) was recorded. The $\mathrm{Z}$ test was conducted to determine the $\mathrm{OR}$, with $\mathrm{P}<0.05$ considered statistical significance. Heterogeneity was investigated using the $\chi^{2}$ test and the $\mathrm{I}^{2}$ test. If significant heterogeneity existed, we employed the random effect model; otherwise, the fixed 


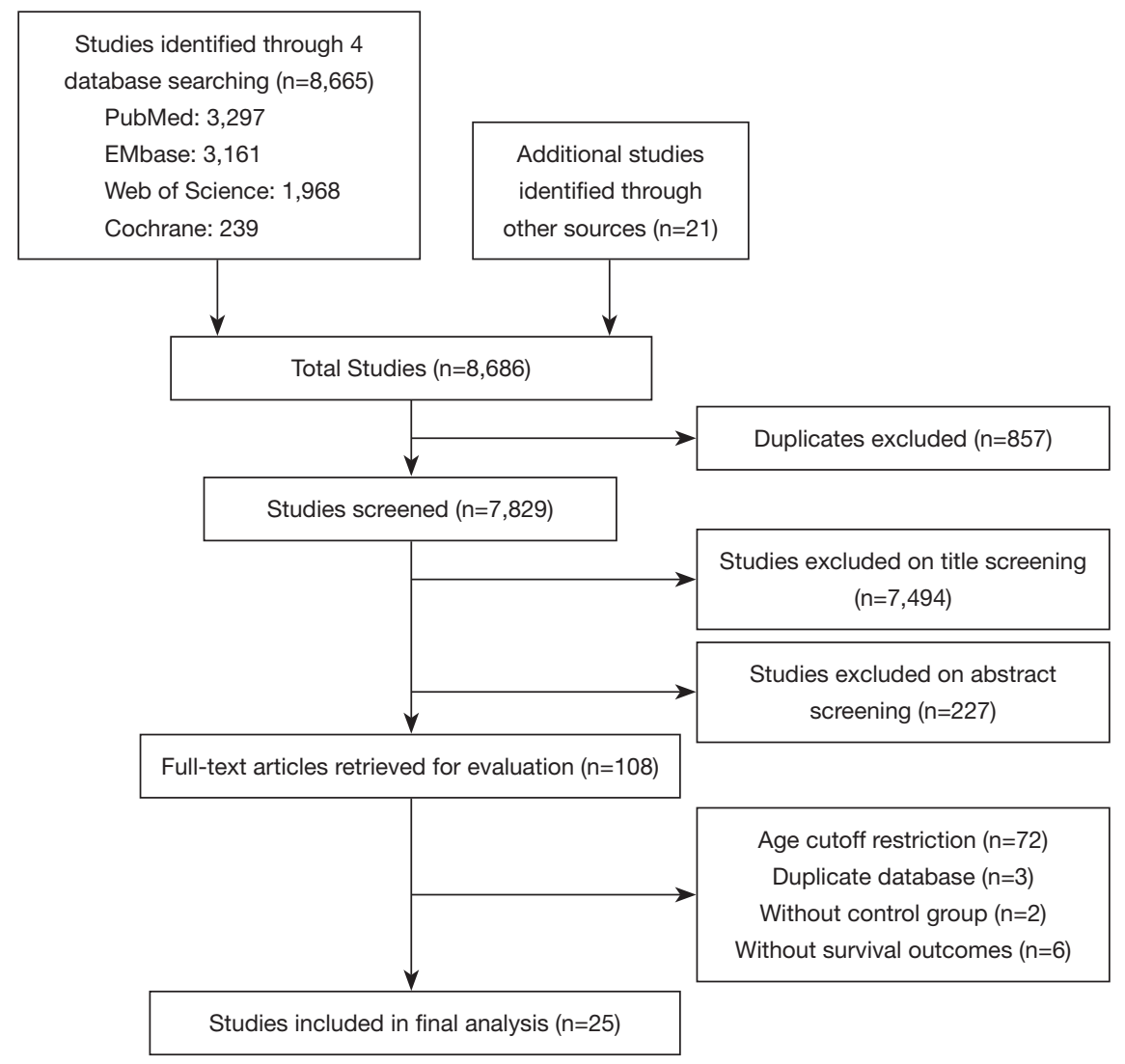

Figure 1 The flow chart of the research process until December 2019.

effects model was adopted (34,35). Sensitivity analyses were undertaken to investigate sources of substantial heterogeneity.

\section{Results}

\section{Studies selection}

Our initial search strategy generated a total of 8,686 relevant clinical studies. After a screening of titles and abstracts, 108 articles were scrutinized by a full-text review. Eighty-three studies were eventually excluded by following the exclusion criteria and inclusion criteria. In total, the eligible 25 clinical studies $(4,5,8-30)$ involving 81,188 gastric cancer patients were entered into the review and meta-analysis, of which one was a prospective study (17), three were multicenter studies $(16,19,21)$, and the rest were all retrospective studies. Figure 1 showed the flow chart of the search process. The NOS scores and essential characteristics of the eligible studies were shown in Table 1.

\section{Clinicopathological characteristics}

The clinicopathologic characteristics of the gastric cancer patients were presented in Tables 2 and S1. Compared with the older group, younger patients with gastric cancer were more often female from pooled 25 studies (OR $=2.09,95 \%$ CI: $1.81-2.41, \mathrm{P}<0.001, \mathrm{I}^{2}=76 \%$ ) (Figure S1). Younger patients were more likely to be a diffuse type $(\mathrm{OR}=4.29$, 95\% CI: $\left.3.15-5.85, \mathrm{P}<0.001, \mathrm{I}^{2}=82 \%\right)$, pTNM stage IV $\left(\mathrm{OR}=1.21,95 \% \mathrm{CI}: 1.08-1.35, \mathrm{P}<0.001, \mathrm{I}^{2}=0\right)$, poorly differentiation $(\mathrm{OR}=3.59,95 \% \mathrm{CI}: 2.89-4.47, \mathrm{P}<0.001$, $\left.\mathrm{I}^{2}=82 \%\right)$, and a signet ring cell carcinoma $(\mathrm{OR}=4.81,95 \%$ CI: 4.33-5.33, $\mathrm{P}<0.001, \mathrm{I}^{2}=0$ ) (Figure S2).

Concerning to therapeutic regimen, six studies showed that younger group had a higher chemotherapy rate when compared to older group (OR $=1.79,95 \%$ CI: $1.49-2.16$, $\left.\mathrm{P}<0.001, \mathrm{I}^{2}=43 \%\right)$. In addition, the proportions of younger patients underwent subtotal gastrectomy or D1 resection were significantly lower than those of the older $(\mathrm{OR}=0.88$, 95\% CI: 0.79-0.99, $\mathrm{P}=0.03, \mathrm{I}^{2}=39 \%$; OR $=0.59,95 \%$ CI: $0.48-0.73, \mathrm{P}<0.001, \mathrm{I}^{2}=25 \%$, respectively). However, there 


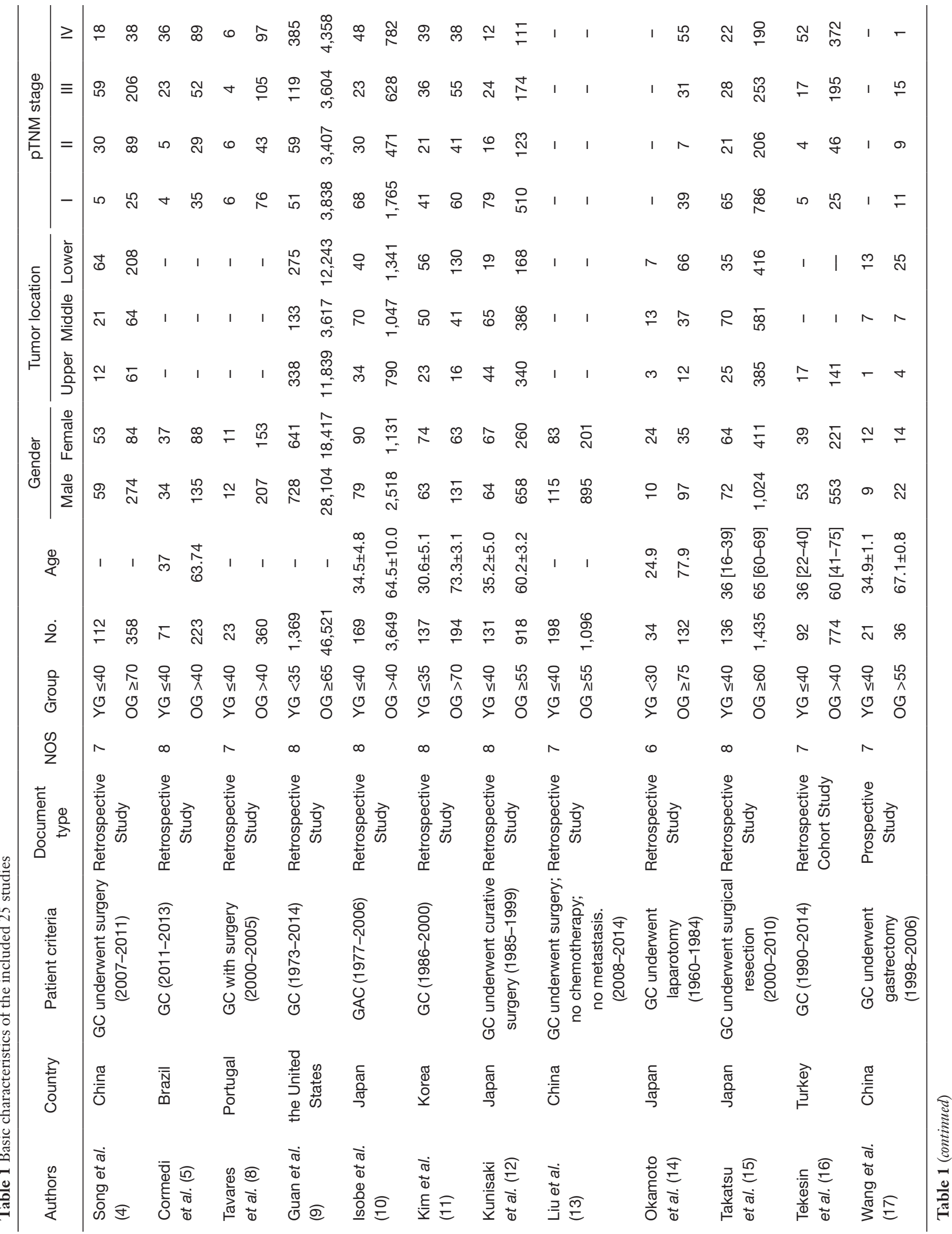




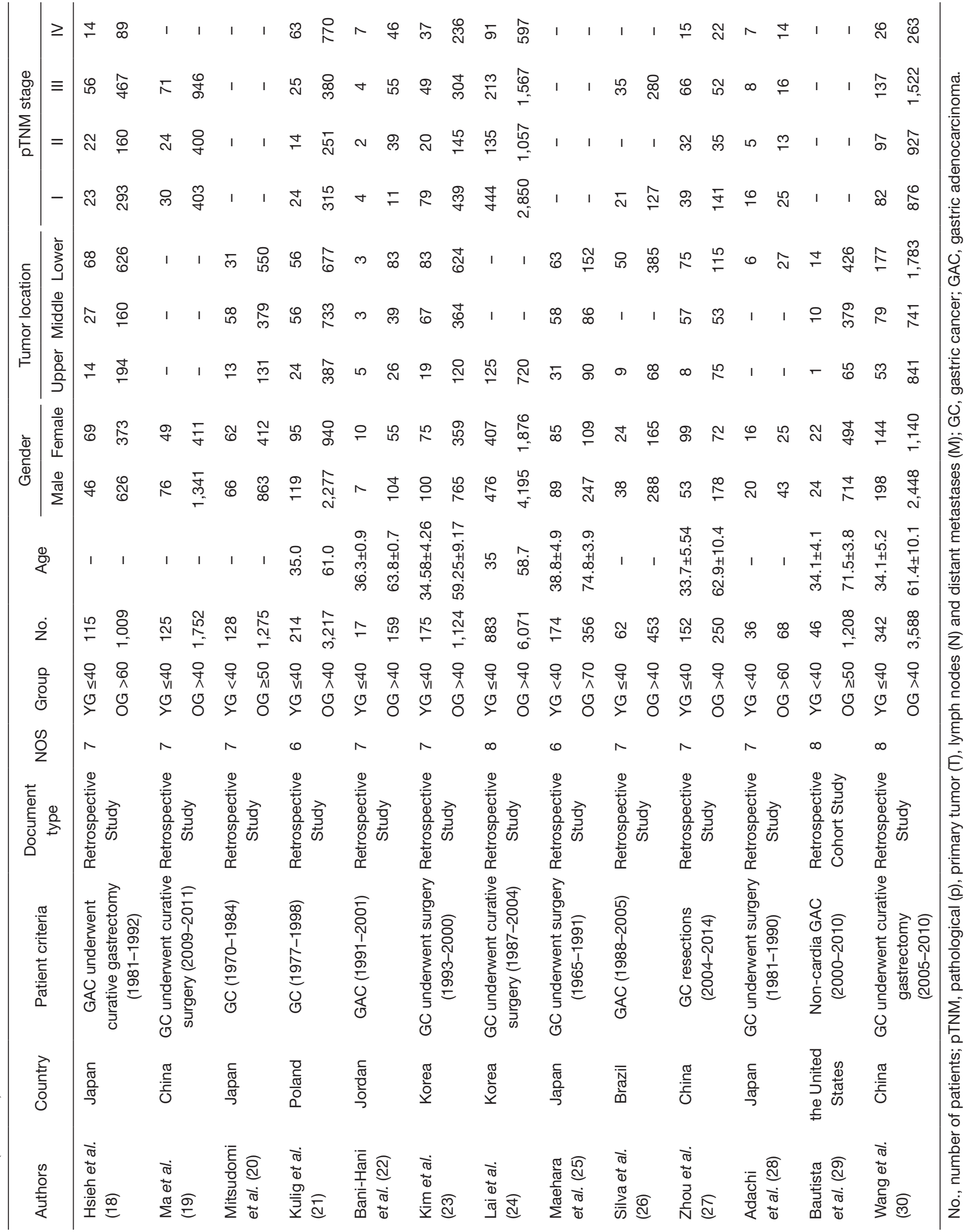


Table 2 Subgroup meta-analysis of clinicopathological characteristics and survival outcomes between the younger group and older group

\begin{tabular}{|c|c|c|c|c|c|c|c|}
\hline Subgroup & $\begin{array}{l}\text { Included } \\
\text { studies }\end{array}$ & $\begin{array}{l}\text { Included } \\
\text { patients }\end{array}$ & $\mathrm{I}^{2}(\%)$ & Effect model & OR/WMD & $95 \% \mathrm{Cl}$ & $P$ \\
\hline Female & 25 & 81,188 & 76 & Random & 2.09 & $1.81-2.41$ & $<0.001$ \\
\hline pTNM stage IV & 16 & 26,202 & 0 & Fixed & 1.21 & $1.08-1.35$ & $<0.001$ \\
\hline Poorly differentiation & 19 & 75,349 & 82 & Random & 3.59 & $2.89-4.47$ & $<0.001$ \\
\hline \multicolumn{8}{|l|}{ Therapeutic regimen } \\
\hline Subtotal gastrectomy & 9 & 14,427 & 39 & Fixed & 0.88 & $0.79-0.99$ & 0.03 \\
\hline Curative gastrectomy & 14 & 18,159 & 10 & Fixed & 0.93 & $0.82-1.06$ & 0.30 \\
\hline Postoperative complications & 5 & 6,309 & 73 & Random & 0.44 & $0.24-0.79$ & 0.006 \\
\hline \multicolumn{8}{|l|}{ Recurrence/metastasis } \\
\hline Peritoneal recurrence & 4 & 1,965 & 11 & Fixed & 1.93 & $1.31-2.84$ & 0.001 \\
\hline Lymph node metastasis & 8 & 3,901 & 0 & Fixed & 0.83 & $0.69-0.98$ & 0.03 \\
\hline Hepatic metastasis & 9 & 11,126 & 0 & Fixed & 0.68 & $0.47-0.98$ & 0.04 \\
\hline Peritoneal metastasis & 9 & 11,695 & 63 & Random & 1.63 & $1.16-2.27$ & 0.004 \\
\hline 5-year OS & 9 & 59,647 & 60 & Random & 1.01 & $0.79-1.30$ & 0.92 \\
\hline 5-year OS underwent curative surgery & 12 & 19,012 & 60 & Random & 1.39 & $1.12-1.72$ & 0.002 \\
\hline Stage I-OS & 4 & 5,261 & 51 & Random & 1.73 & $0.86-3.49$ & 0.13 \\
\hline Stage II-OS & 4 & 2,771 & 51 & Random & 0.95 & $0.60-1.51$ & 0.83 \\
\hline Stage III-OS & 4 & 4,639 & 0 & Fixed & 1.29 & $1.05-1.58$ & 0.01 \\
\hline Stage IV-OS & 3 & 1,016 & 0 & Fixed & 1.86 & $1.20-2.89$ & 0.006 \\
\hline
\end{tabular}

pTNM, pathological $(p)$, primary tumor $(T)$, lymph nodes $(N)$ and distant metastases $(M)$; SRCC, signet ring cell carcinoma; OS, overall survival. 
were no statistical differences in curative resection rate between the two groups $(\mathrm{OR}=0.93 ; 95 \% \mathrm{CI}$ : $0.82-1.06$, $\mathrm{P}=0.30, \mathrm{I}^{2}=10 \%$ ) (Figure S3).

\section{Postoperative complications}

A total of 6,309 patients from five studies were enrolled in postoperative complications. The result revealed that the proportion of complications in younger patients was significantly lower compared to the older (OR $=0.44,95 \%$ CI: $0.24-0.79, \mathrm{P}=0.006)$, and the heterogeneity between the younger and older group was significant $\left(\mathrm{I}^{2}=73 \%\right)$ (Figure S4).

\section{Survival outcomes}

Figure 2 presented the meta-analysis of the 5-year overall survival (OS) with total patients, gastrectomy group, and only curative gastrectomy group, respectively. There was no significant difference for total patients based on the nine included studies ( $\mathrm{OR}=1.01,95 \% \mathrm{CI}$ : 0.79-1.30, $\left.\mathrm{P}=0.92, \mathrm{I}^{2}=60 \%\right)$. However, the pooled 18 and 12 studies respectively showed that younger adults in gastrectomy group and only curative gastrectomy group were associated with better survival relative to that of the older $(\mathrm{OR}=1.35$, 95\% CI: $1.16-1.57, \mathrm{P}<0.001, \mathrm{I}^{2}=56 \%$; OR $=1.39,95 \% \mathrm{CI}$ : $\left.1.12-1.72, \mathrm{P}=0.002, \mathrm{I}^{2}=60 \%\right)$.

Moreover, further survival analyses between younger and older patients were done under the different pTNM tumor stage. Four of the studies provided survival rates for gastrectomy group, and the meta-analysis showed that younger patients at pTNM stage I, stage III, and stage IV were associated with better 5 -year OS than older (OR $=2.38,95 \%$ CI: $1.56-3.61, \mathrm{P}<0.001, \mathrm{I}^{2}=11 \%$; OR =1.36, 95\% CI: $1.14-1.63, \mathrm{P}<0.001, \mathrm{I}^{2}=27 \%$; OR $=1.93,95 \% \mathrm{CI}$ : $1.30-2.85, \mathrm{P}=0.001, \mathrm{I}^{2}=0 \%$, respectively) (Figure 3). For the only curative gastrectomy group, three of the included studies revealed that younger patients at pTNM stage III and stage IV also had improved survival (OR $=1.29$, 95\% CI: $1.05-1.58, \mathrm{P}=0.01, \mathrm{I}^{2}=0 \%$; OR $=1.86,95 \% \mathrm{CI}$ : 1.20-2.89, $\mathrm{P}=0.006, \mathrm{I}^{2}=0 \%$, respectively), but there was no statistical difference in gastric cancer at stage I (OR $=1.73$, 95\% CI: $0.86-3.49, \mathrm{P}=0.13, \mathrm{I}^{2}=51 \%$ ) (Figure 4). The short-term (including the 1-, 2-, 3-year) survival rates were presented in Table $S 2$.

Concerning to the metastasis status of gastric cancer, nine of the 25 studies showed that younger group was predominant in peritoneal metastasis $(\mathrm{OR}=1.63,95 \%$
CI: $\left.1.16-2.27, \mathrm{P}=0.004, \mathrm{I}^{2}=63 \%\right)$. Some included studies reported the lymph node metastasis and hepatic metastasis of gastric cancer, and our result showed that both lymph node metastasis and hepatic metastasis ratio was lower in younger group compared with those of the older (OR $=0.83$, 95\% CI: $0.69-0.98, \mathrm{P}=0.03, \mathrm{I}^{2}=0 \%$; OR $=0.68,95 \%$ CI: $0.47-0.98, \mathrm{P}=0.04, \mathrm{I}^{2}=0 \%$ ). In addition, 4 related studies indicated that the incidence of peritoneal recurrence was significantly higher in younger group $(\mathrm{OR}=1.93,95 \% \mathrm{CI}$ : 1.31-2.84, $\mathrm{P}=0.001, \mathrm{I}^{2}=11 \%$ ) (Figure $S 5$ and Table S3).

\section{Discussion}

The review and meta-analysis involved 24 retrospective comparative trails and one prospective study with 81,188 patients with gastric cancer. Our findings demonstrated that the younger group after gastrectomy or only curative gastrectomy was correlated with a better OS, but there was no significant difference for total patients between the two groups. To our best knowledge, this analysis was the most extensive evaluation to compare the clinicopathological feature and prognosis between the younger and older group.

Several findings regarding the clinicopathological characteristics in the meta-analysis were in agreement with previous researches, including a higher proportion of female, poorly differentiation, signet ring cell carcinoma, diffuse histology, and pTNM tumor stage IV in younger adults (8-21). Our survey revealed that younger patients had a higher proportion of females, while male predominance was mostly seen in the older group. Although the reasons for female predominance in younger patients were not clear, some potential explanations had been identified. Several studies considered hormonal factors, such as estrogens and higher percentages of estrogen receptor-positive cells might be associated with the predominance of younger females $(36,37)$. Compared to older patients, younger patients with gastric cancer had been believed to be related to genetic changes rather than environmental factors (38). Thereby more frequent exposure to environmental carcinogens, such as cigarettes, might lead to the dominance among older male patients (39). Concerning to histological type, our analysis revealed that poorly differentiation, diffusetype, and signet ring cell carcinoma were predominant in the younger group. In comparison, more patients in the older group were diagnosed as intestinal type and mucous adenocarcinoma. The primary reason may be germline mutations, specifically in the $C D H 1$ gene, as reported in 
A

\begin{tabular}{|c|c|c|c|c|c|}
\hline \multirow[b]{2}{*}{ Studv or Subgroup } & \multicolumn{2}{|c|}{ Younger group } & \multicolumn{2}{|c|}{ Older group } & \multirow{2}{*}{ Weight } \\
\hline & Events & Total & Events & Total & \\
\hline Bani 2005 & 8 & 92 & 83 & 774 & $7.5 \%$ \\
\hline Bautista and Jiang et al 2014 & 28 & 62 & 140 & 453 & $11.6 \%$ \\
\hline Cormedi and Katayama et al 2018 & 98 & 169 & 2346 & 3649 & $18.3 \%$ \\
\hline Guan and Yuan et al 2019 & 82 & 128 & 778 & 1275 & $16.1 \%$ \\
\hline Isobe and Hashimoto et al 2013 & 23 & 71 & 55 & 223 & $10.6 \%$ \\
\hline Kulig and Popiela et al 2008 & 0 & 214 & 0 & 3217 & \\
\hline Mitsudomi and Matsusaka et al 1989 & 329 & 1369 & 13649 & 46521 & $24.3 \%$ \\
\hline Silva and Begnami et al 2008 & 9 & 46 & 217 & 1208 & $7.7 \%$ \\
\hline Tekesin and Gunes et al 2019 & 4 & 17 & 34 & 159 & $3.7 \%$ \\
\hline Total $(95 \% \mathrm{Cl})$ & & 2168 & & 57479 & $100.0 \%$ \\
\hline Total events & 581 & & 17302 & & \\
\hline Heterogeneity. $\mathrm{Tau}^{2}=0.06 ; \mathrm{Chi}^{2}=1$ & $=7(P$ & م01) & ${ }^{2}=60 \%$ & & \\
\hline
\end{tabular}

Odds Ratio

Odds Ratio

Random, 95\% C

$0.79[0.37,1.70]$

$1.84[1.07,3.15]$

$0.77[0.56,1.05]$

$1.14[0.78,1.66]$

$1.46[0.82,2.62]$

Not estimable

$0.76[0.67,0.86]$

$1.11[0.53,2.34]$

$1.13[0.35,3.69]$

$1.01[0.79,1.30]$ Test for overall effect $Z=0.10(P=0.92)$

B

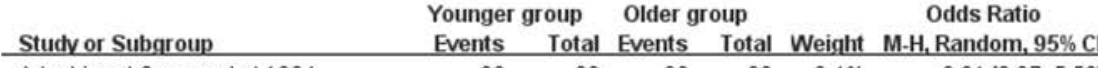

Adachi and Ogawa et al 1994

Hsieh and Wang et al 2012

Isobe and Hashimoto et al 2013

$2.31[0.97,5.521$

$0.97[0.66,1.43]$

$1.26[0.70,2.27]$

$\mathrm{Kim}$ and $\mathrm{B} 00$ et al 2008

Kim and Joo et al 2005

Kulig and Popiela et al 2008

Kunisaki and Akiyama et al 2006

Lai and Kim et al 2008

Liu and Feng et al 2016

$\mathrm{Ma}$ and Ren et al 2018

Maehara and Emi et al1996

Mitsudomi and Matsusaka et al 1989

Okamoto and Makino et al 1988

Song and Li et al 2017

Takatsu and Hiki et al 2016

Tavares and Gandra et al 2013

Wang and $\mathrm{Hsieh}$ et al 1996

Wang and $X u$ et al 2016

$\begin{array}{rrrrrr}26 & 36 & 36 & 68 & 2.4 \% & 2.31[0.97,5.52] \\ 60 & 115 & 525 & 991 & 6.8 \% & 0.97[0.66,1.43] \\ 99 & 112 & 2341 & 2728 & 4.3 \% & 1.26[0.70,2.27] \\ 106 & 175 & 616 & 1124 & 7.9 \% & 1.27[0.92,1.75]\end{array}$

$\begin{array}{rrrrrr}106 & 175 & 616 & 1124 & 7.9 \% & 1.27[0.92,1.75] \\ 77 & 137 & 125 & 194 & 5.9 \% & 0.71[0.45,1.11]\end{array}$

$\begin{array}{llrrrr}0 & 152 & 0 & 2093 & \text { Not estimable }\end{array}$

$\begin{array}{rrrrr}99 & 131 & 679 & 918 & 6.3 \%\end{array}$

$\begin{array}{lllll}706 & 883 & 4030 & 5491 & 10.7 \%\end{array}$

$1.09[0.71,1.67]$

$1.45[1.21,1.72]$

$1.39[1.01,1.89]$

$0.85[0.59,1.23]$

$2.18[1.51,3.15]$

$1.61[0.95,2.73]$

$1.65[0.67,4.07]$

$2.17[1.41,3.34]$

$1.43[0.92,2.22]$

$3.06[1.30,7.19]$

$0.88[0.30,2.59]$

$1.34[1.07,1.68]$

Total $(95 \% \mathrm{Cl})$

$2998 \quad 23772 \quad 100.0 \%$

$1.35[1.16,1.57]$

Total events $1952 \quad 14183$

Heterogeneity: $\mathrm{Tau}^{2}=0.05 ; \mathrm{Chi}^{2}=36.00, \mathrm{df}=16(\mathrm{P}=0.003) ; \mathrm{I}^{2}=56 \%$

Test for overall effect $Z=3.89(P<0.0001)$

C

\begin{tabular}{|c|c|c|c|c|c|}
\hline \multirow[b]{2}{*}{ Studv or Subgroup } & \multicolumn{2}{|c|}{ Younger group } & \multicolumn{2}{|c|}{ Older group } & \multirow[b]{2}{*}{ Weight } \\
\hline & Events & Total & Events & Total & \\
\hline Adachi and Ogawa et al 1994 & 25 & 29 & 34 & 44 & $2.4 \%$ \\
\hline Isobe and Hashimoto et al 2013 & 99 & 112 & 2341 & 2728 & $7.4 \%$ \\
\hline Kim and Boo et al 2008 & 101 & 144 & 577 & 888 & $11.2 \%$ \\
\hline Kim and Joo et al 2005 & 68 & 101 & 94 & 157 & $8.4 \%$ \\
\hline Kunisaki and Akiyama et al 2006 & 96 & 121 & 658 & 827 & $9.4 \%$ \\
\hline Lai and Kim et al 2008 & 706 & 883 & 4030 & 5491 & $15.7 \%$ \\
\hline Ma and Ren et al 2018 & 70 & 125 & 1049 & 1752 & $11.5 \%$ \\
\hline Maehara and Emi et al1996 & 94 & 103 & 161 & 255 & $5.7 \%$ \\
\hline Mitsudomi and Matsusaka et al 1989 & 85 & 103 & 802 & 1076 & $8.4 \%$ \\
\hline Okamoto and Makino et al 1988 & 11 & 14 & 39 & 72 & $2.1 \%$ \\
\hline Wang and Hsieh et al 1996 & 11 & 21 & 20 & 36 & $3.1 \%$ \\
\hline Wang and $X u$ et al 2016 & 208 & 342 & 1927 & 3588 & $14.6 \%$ \\
\hline Total $(95 \% \mathrm{Cl})$ & & 2098 & & 16914 & $100.0 \%$ \\
\hline Total events & 1574 & & 11732 & & \\
\hline Heterogeneity: $\mathrm{Tau}^{2}=0.07 ; \mathrm{Chi}^{2}=27$ & $\mathrm{f}=11$ & $0.004)$ & $I^{2}=609$ & & \\
\hline
\end{tabular}

H. Random, 95\% Cl

$1.84[0.52,6.54]$

$1.26[0.70,2.27]$

$1.27[0.86,1.86]$

$1.38[0.82,2.33]$

$0.99[0.62,1.58]$

$1.45[1.21,1.72]$

$0.85[0.59,1.23]$

$6.10[2.94,12.65]$

$1.61[0.95,2.73]$

$3.10[0.80,12.07]$

$0.88[0.30,2.59]$

$1.34[1.07,1.68]$

$1.39[1.12,1.72]$

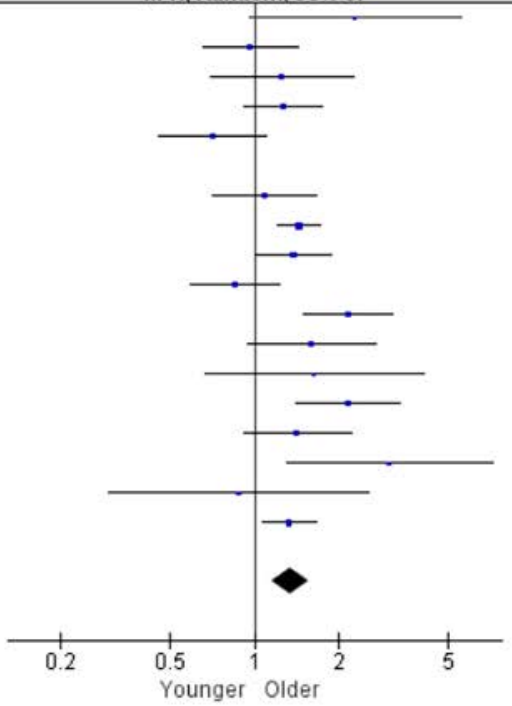
M.H. Random. 95\% C

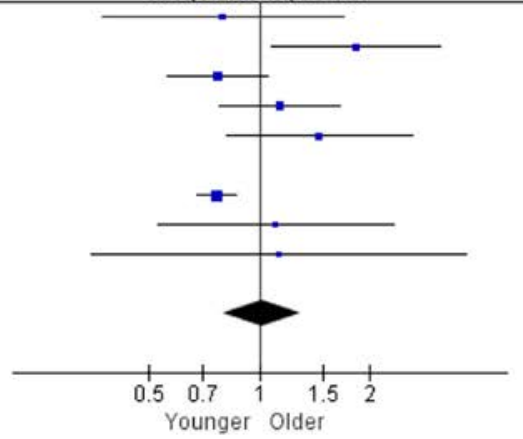
M.H. Random. $95 \% \mathrm{Cl}$

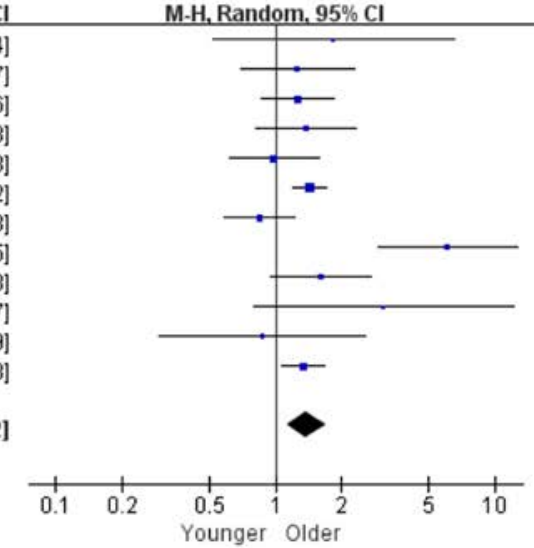

Figure 2 The 5-year overall survival for gastric cancer between younger and older group. (A) The 5-year overall survival of total patients; (B) the 5 -year overall survival of patients underwent gastrectomy; (C) the 5-year overall survival of patients underwent curative gastrectomy. 


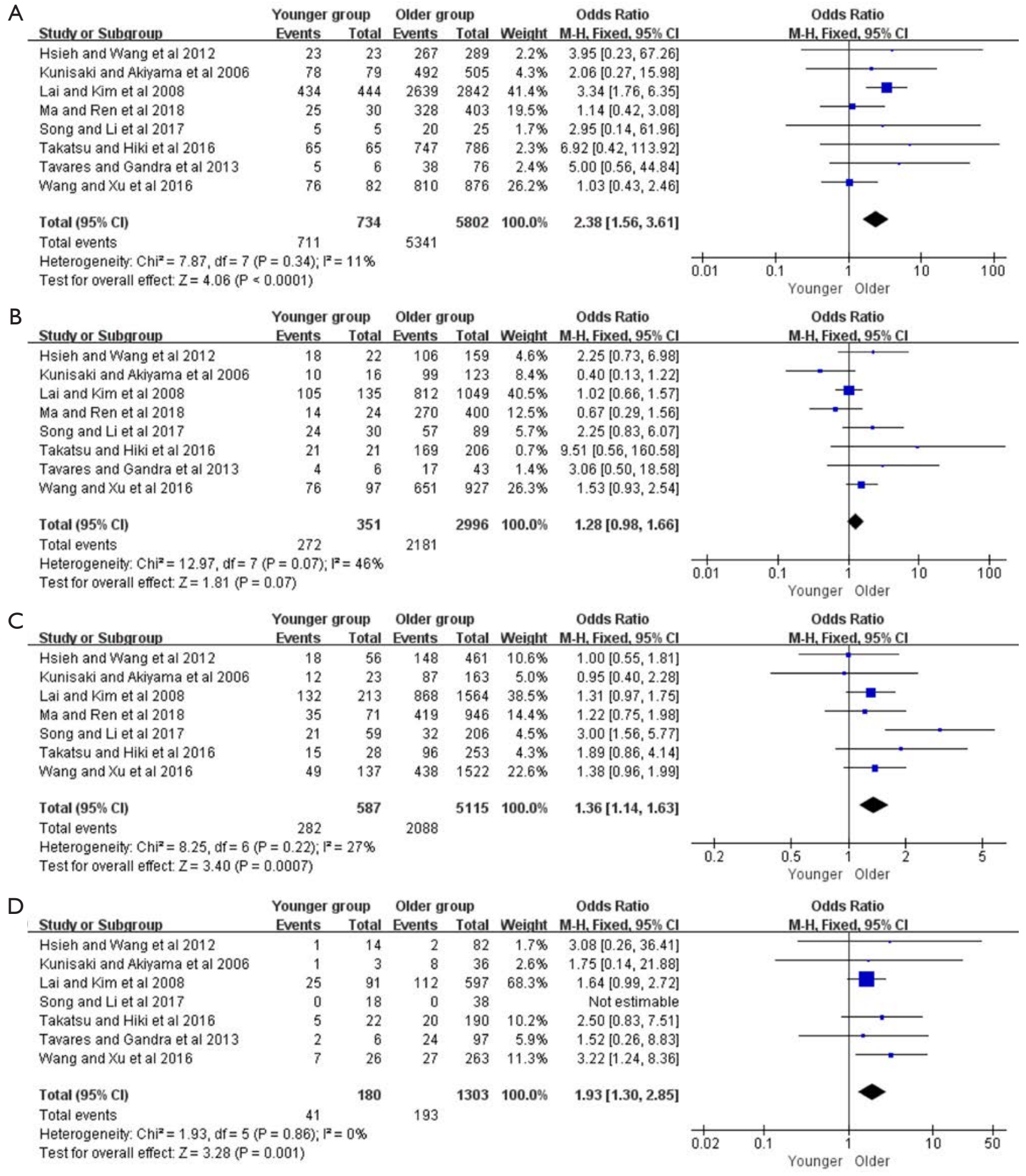

Figure 3 The 5 -year overall survival of gastric cancer underwent gastrectomy between younger and older group. (A) Meta-analysis of patients at pTNM stage I; (B) meta-analysis of patients at pTNM stage II; (C) meta-analysis of patients at pTNM stage III; (D) metaanalysis of patients at p'TNM stage IV. 


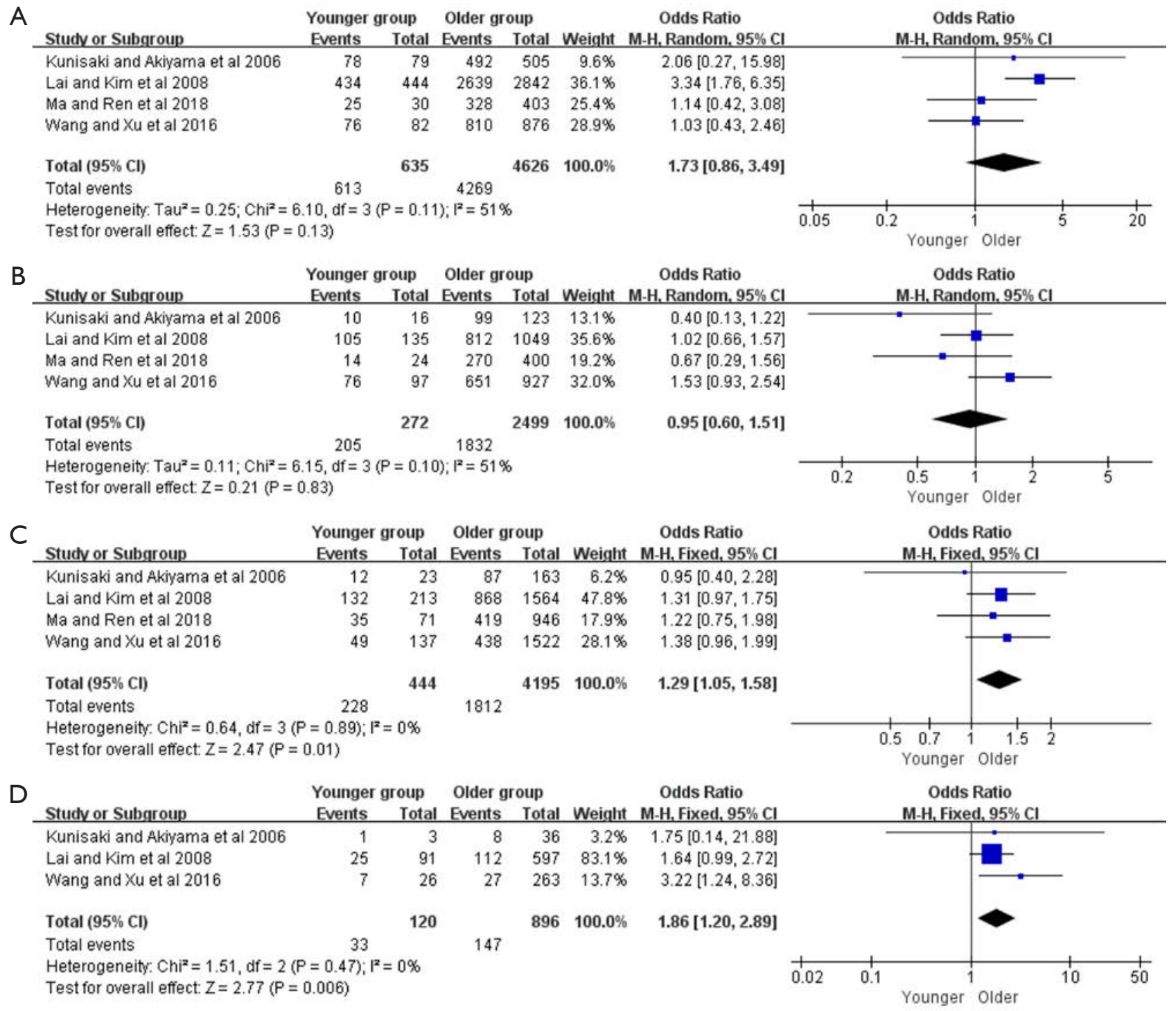

Figure 4 The 5-year overall survival of gastric cancer underwent curative gastrectomy between younger and older group. (A) Meta-analysis of patients at pTNM stage I. (B) meta-analysis of patients at pTNM stage II; (C) meta-analysis of patients at pTNM stage III; (D) metaanalysis of patients at pTNM stage IV.

some researches $(26,40,41)$. While the included studies rarely capture the duration of symptoms before initial diagnosis, other researches have reported delayed diagnosis, and hereditary factors may be closely correlated with advanced gastric cancer $(42,43)$.

Surgery, especially curative resection, was an important approach for patients with gastric cancer (44). There were higher proportions of chemotherapy and $\geq$ D2 lymphadenectomy in the younger group compared with the older. However, the percentages of total gastrectomy and curative resection revealed no statistical differences between younger and older groups, while subtotal gastrectomy was frequently performed in older patients. These results may be due to the significant comorbidities and impairment of functional status in older patients (45-47). Moreover, a previous study demonstrated that the ratio of older patients who had other synchronous or previous malignancies at initial diagnosis was up to $21 \%$ based on Munich Cancer Registry data (48). In our review, postoperative complications were more prevalent in the 
older group, which also reflected a worse tolerance for surgery or chemotherapy. Several studies investigated that the incidence of postoperative complications was closely correlated with poor prognosis $(49,50)$, thus providing a survival advantage for the younger group.

In this analysis, a tendency of peritoneal metastasis in the younger group may reflect the genetic susceptibility, such as $\mathrm{CDH} 1$ and RhoA, that could lead to more aggressive biological behaviors $(40,51)$. Moreover, the infiltration of poorly differentiated gastric cancer was more pronounced in the vertical direction, thus conferring lymph node involvement and peritoneal dissemination. Metastasis was the leading cause of recurrence, and it had been thought that peritoneal metastasis was the most common form of repetition in gastric carcinoma (15). Our finding indicated a higher incidence of peritoneal recurrence in younger patients, which was similar to the other conclusion (12).

Younger gastric cancer patients as a group revealed similar long-term OS compared to older, and this finding was consistent with previous studies $(5,10,11,20)$. In the subgroups of gastrectomy and only curative gastrectomy, both the short-term (including the 1-, 2-, 3-year) and long-term (including the 5-year) OS for older group was more miserable than those of the younger group, possibly due to a more significant percentage of comorbidities and complications. When the 5-year OS under different pTNM stages was evaluated, the results differed substantially between the younger and older group. A trend towards better long-term survival in the younger group may reflect a higher tolerance for the patients given a younger age and fewer comorbidities. Moreover, the shorter life expectancy of the older group compared to the younger may also be responsible.

There were several limitations in the analysis because of the characteristics of the included studies identified. Firstly, only one of the trials we identified was a prospective study. Secondly, most of the included studies were from Eastern Asia, which might not have a great representative and guiding value across the globe, especially in Western countries. Thereby, more related researches were expected to evaluate in gastric cancer patients at a younger age. Thirdly, there were inevitable heterogeneities, such as female ratio, diffuse type, as well as several survival variables in the analysis. The contribution of each included study to the pooled estimate was evaluated in the sensitivity analyses, and the result showed that sources of these heterogeneities were mainly from the selection bias. Furthermore, the lack of available patient data did not allow our analysis to assess disease-specific survival and disease-free survival. Despite these limitations, the study to our knowledge was the most extensive analysis evaluating the clinicopathological characteristics and survival outcomes in the younger and older patients, which may overcome the limitation of small sample size and single-institution targeted the field. Besides, all of the clinical studies involved in the meta-analysis had a high quality and met our inclusion criteria, thus might provide more valuable resources for the clinicians in patients' management and decision-making.

\section{Conclusions}

In conclusion, younger patients with gastric cancer were more often diagnosed as poorly differentiation and later pTNM tumor stage. However, younger cancer patients following gastrectomy had a better OS rate than patients in older group. Future large-scale analyses are expected to confirm our findings.

\section{Acknowledgments}

Funding: this study was funded in part by the National Key R\&D Program of China (Grant No. 2017YFC0908300).

\section{Footnote}

Reporting Checklist: The authors have completed the PRISMA reporting checklist. Available at http://dx.doi. org/10.21037/tcr-20-2024

Conflicts of Interest: All authors have completed the ICMJE uniform disclosure form (available at http://dx.doi. org/10.21037/tcr-20-2024). The authors have no conflicts of interest to declare.

Ethical Statement: The authors are accountable for all aspects of the work in ensuring that questions related to the accuracy or integrity of any part of the work are appropriately investigated and resolved.

Open Access Statement: This is an Open Access article distributed in accordance with the Creative Commons Attribution-NonCommercial-NoDerivs 4.0 International License (CC BY-NC-ND 4.0), which permits the noncommercial replication and distribution of the article with the strict proviso that no changes or edits are made and the original work is properly cited (including links to both the 
formal publication through the relevant DOI and the license). See: https://creativecommons.org/licenses/by-nc-nd/4.0/.

\section{References}

1. Bray F, Ferlay J, Soerjomataram I, et al. Global cancer statistics 2018. GLOBOCAN estimates of incidence and mortality worldwide for 36 cancers in 185 countries. CA Cancer J Clin 2018;68:394-424.

2. Ferlay J, Colombet M, Soerjomataram I, et al. Estimating the global cancer incidence and mortality in 2018: GLOBOCAN sources and methods. Int J Cancer 2019;144:1941-53.

3. Anderson WF, Camargo MC, Fraumeni JF Jr, et al. Agespecific trends in incidence of noncardia gastric cancer in US adults. JAMA 2010;303:1723-8.

4. Song S, Li C, Li S, et al. Clinicopathological features and prognoses in younger and older patients with gastric cancer. Onco Targets Ther 2017;10:4795-802.

5. Cormedi MCV, Katayama MLH, Guindalini RSC, et al. Survival and prognosis of young adults with gastric cancer. Clinics (Sao Paulo) 2018;73:e651s.

6. Nakamura R, Saikawa Y, Takahashi T, et al. Retrospective analysis of prognostic outcome of gastric cancer in young patients. Int J Clin Oncol 2011;16:328-34.

7. Smith BR, Stabile BE. Extreme aggressiveness and lethality of gastric adenocarcinoma in the very young. Arch Surg 2009;144:506-10.

8. Tavares A, Gandra A, Viveiros F, et al. analysis of clinicopathologic characteristics and prognosis of gastric cancer in young and older patients. Pathol Oncol Res 2013;19:111-7.

9. Guan WL, Yuan LP, Yan XL, et al. More attention should be paid to adult gastric cancer patients younger than 35 years old: extremely poor prognosis was found. J Cancer 2019;10:472-8.

10. Isobe T, Hashimoto K, Kizaki J, et al. Characteristics and prognosis of gastric cancer in young patients. Oncol Rep 2013;30:43-9.

11. Kim DY, Joo JK, Ryu SY, et al. Clinicopathologic characteristics of gastric carcinoma in elderly patients: a comparison with young patients. World J Gastroenterol 2005;11:22-6.

12. Kunisaki C, Akiyama H, Nomura M, et al. Clinicopathological features of gastric carcinoma in younger and middle-aged patients. a comparative study. J Gastrointest Surg 2006;10:1023-32.

13. Liu S, Feng F, Xu G, et al. Clinicopathological features and prognosis of gastric cancer in young patients. BMC Cancer 2016;16:478.

14. Okamoto T, Makino M, Kawasumi H, et al. Comparative study of gastric cancer in young and aged patients. Eur Surg Res 1988;20:149-55.

15. Takatsu Y, Hiki N, Nunobe S, et al. Clinicopathological features of gastric cancer in young patients. Gastric Cancer 2016;19:472-8.

16. Tekesin K, Emin Gunes M, Tural D, et al. Clinicopathological characteristics, prognosis and survival outcome of gastric cancer in young patients: a large cohort retrospective study. J BUON 2019;24:672-8.

17. Wang JY, Hsieh JS, Huang CJ, et al. Clinicopathologic study of advanced gastric cancer without serosal invasion in young and old patients. J Surg Oncol 1996;63:36-40.

18. Hsieh FJ, Wang YC, Hsu JT, et al. Clinicopathological features and prognostic factors of gastric cancer patients aged 40 years or younger. J Surg Oncol 2012;105:304-9.

19. Ma X, Ren D, Kan J, et al. Clinicopathological Characteristics and Prognoses of Elderly Gastric Cancer Patients after R0 Resection. A Multicenter Study in China. J Environ Pathol Toxicol Oncol 2018;37:81-91.

20. Mitsudomi T, Matsusaka T, Wakasugi K, et al. A clinicopathological study of gastric cancer with special reference to age of the patients. an analysis of 1,630 cases. World J Surg 1989;13:225-30; discussion 230-1.

21. Kulig J, Popiela T, Kolodziejczyk P, et al. Clinicopathological profile and long-term outcome in young adults with gastric cancer: multicenter evaluation of 214 patients. Langenbecks Arch Surg 2008;393:37-43.

22. Bani-Hani KE. Clinicopathological comparison between young and old age patients with gastric adenocarcinoma. Int J Gastrointest Cancer 2005;35:43-52.

23. Kim JH, Boo YJ, Park JM, et al. incidence and longterm outcome of young patients with gastric carcinoma according to sex: does hormonal status affect prognosis? Arch Surg 2008;143:1062-7; discussion 1067.

24. Lai JF, Kim S, Li C, et al. Clinicopathologic characteristics and prognosis for young gastric adenocarcinoma patients after curative resection. Ann Surg Oncol 2008;15:1464-9.

25. Maehara Y, Emi Y, Tomisaki S, et al. Age-related characteristics of gastric carcinoma in young and elderly patients. Cancer 1996;77:1774-80.

26. Silva EM, Begnami MD, Fregnani JH, et al. Cadherincatenin adhesion system and mucin expression. a comparison between young and older patients with gastric carcinoma. Gastric Cancer 2008;11:149-59.

27. Zhou F, Shi J, Fang C, et al. Gastric carcinomas in young 
(younger than 40 years) Chinese patients: clinicopathology, family history, and postresection survival. Medicine (Baltimore) 2016;95:e2873.

28. Adachi Y, Ogawa Y, Sasaki Y, et al. A clinicopathologic study of gastric carcinoma with reference to age of patients. J Clin Gastroenterol 1994;18:287-90.

29. Bautista MC, Jiang SF, Armstrong MA, et al. Impact of age on clinicopathological features and survival of patients with noncardia gastric adenocarcinoma. J Gastric Cancer 2014;14:238-45.

30. Wang Z, Xu J, Shi Z, et al. Clinicopathologic characteristics and prognostic of gastric cancer in young patients. Scand J Gastroenterol 2016;51:1043-9.

31. Kong X, Wang JL, Chen HM, et al. Comparison of the clinicopathological characteristics of young and elderly patients with gastric carcinoma: a meta analysis. J Surg Oncol 2012;106:346-52.

32. Jiang L, Yang KH, Chen Y, et al. Systematic review and meta-analysis of the effectiveness and safety of extended lymphadenectomy in patients with resectable gastric cancer. Br J Surg 2014;101:595-604.

33. Stang A. Critical evaluation of the Newcastle-Ottawa scale for the assessment of the quality of nonrandomized studies in meta-analyses. Eur J Epidemiol 2010;25:603-5.

34. DerSimonian R, Kacker R. Random-effects model for meta-analysis of clinical trials. an update. Contemp Clin Trials 2007;28:105-14.

35. DerSimonian R, Laird N. Meta-analysis in clinical trials revisited. Contemp Clin Trials 2015;45:139-45.

36. Camargo MC, Goto Y, Zabaleta J, et al. Sex hormones, hormonal interventions, and gastric cancer risk: a meta-analysis. Cancer Epidemiol Biomarkers Prev 2012;21:20-38.

37. Wang Z, Butler LM, Wu AH, et al. Reproductive factors, hormone use and gastric cancer risk: The Singapore Chinese Health Study. Int J Cancer 2016;138:2837-45.

38. Liu Y, Kaneko S, Sobue T. Trends in reported incidences of gastric cancer by tumour location, from 1975 to 1989 in Japan. Int J Epidemiol 2004;33:808-15.

39. Green J, Roddam A, Pirie K, et al. Reproductive factors and risk of oesophageal and gastric cancer in the Million

Cite this article as: Niu P, Zhao L, Ling R, Zhao D, Chen Y. Clinicopathological characteristics and survival outcomes of younger patients with gastric cancer: a systematic review and meta-analysis. Transl Cancer Res 2020;9(10):60266038. doi: $10.21037 /$ tcr-20-2024
Women Study cohort. Br J Cancer 2012;106:210-6.

40. Huntsman DG, Carneiro F, Lewis FR, et al. Early gastric cancer in young, asymptomatic carriers of germline E-cadherin mutations. N Engl J Med 2001;344:1904-9.

41. Suriano G, Yew S, Ferreira P, et al. Characterization of a recurrent germ line mutation of the E-cadherin gene: implications for genetic testing and clinical management. Clin Cancer Res 2005;11:5401-9.

42. Koea JB, Karpeh MS, Brennan MF. Gastric cancer in young patients: demographic, clinicopathological, and prognostic factors in 92 patients. Ann Surg Oncol 2000;7:346-51.

43. Chung HW, Noh SH, Lim JB. Analysis of demographic characteristics in 3242 young age gastric cancer patients in Korea. World J Gastroenterol 2010;16:256-63.

44. Japanese Gastric Cancer Association. Japanese gastric cancer treatment guidelines 2014 (ver. 4). Gastric Cancer 2017;20:1-19.

45. Tsujitani S, Katano K, Oka A, et al. Limited operation for gastric cancer in the elderly. Br J Surg 1996;83:836-9.

46. Korenaga D, Baba H, Kakeji Y, et al. Comparison of R1 and R2 gastrectomy for gastric cancer in patients over 80 years of age. J Surg Oncol 1991;48:136-41.

47. Haga Y, Yagi Y, Ogawa M. Less-invasive surgery for gastric cancer prolongs survival in patients over 80 years of age. Surg Today 1999;29:842-8.

48. Schlesinger-Raab A, Mihaljevic AL, Egert S, et al. Outcome of gastric cancer in the elderly: a populationbased evaluation of the Munich Cancer Registry. Gastric Cancer 2016;19:713-22.

49. Kubota T, Hiki N, Sano T, et al. Prognostic significance of complications after curative surgery for gastric cancer. Ann Surg Oncol 2014;21:891-8.

50. Rizk NP, Bach PB, Schrag D, et al. The impact of complications on outcomes after resection for esophageal and gastroesophageal junction carcinoma. J Am Coll Surg 2004;198:42-50.

51. Carneiro F, Huntsman DG, Smyrk TC, et al. Model of the early development of diffuse gastric cancer in E-cadherin mutation carriers and its implications for patient screening. J Pathol 2004;203:681-7. 


\begin{tabular}{|c|c|c|c|c|c|c|c|c|c|c|c|c|c|c|c|c|c|}
\hline \multirow{2}{*}{ Authors } & \multirow{2}{*}{ Group } & \multirow{2}{*}{ No. } & \multirow{2}{*}{ Tumor size \pm SD $(\mathrm{cm})$} & \multirow{2}{*}{ Pain } & \multirow{2}{*}{ Bleeding } & \multirow{2}{*}{$\begin{array}{c}\text { Cardiopulmonary } \\
\text { disease }\end{array}$} & \multicolumn{2}{|c|}{ Differentiation } & \multirow{2}{*}{ SRCC } & \multirow{2}{*}{ Mucinous } & \multicolumn{3}{|c|}{ Lauren type } & \multicolumn{4}{|c|}{ Borrmann classification } \\
\hline & & & & & & & Well & Poor & & & Intestinal & Diffuse & Mixed & 1 & II & III & IV \\
\hline \multirow{2}{*}{$\begin{array}{l}\text { Song } \\
\text { et al. (4) }\end{array}$} & $Y G$ & 112 & $\leq 6 n=70 ;>6 n=42$ & - & - & - & 6 & 106 & - & - & - & - & - & - & - & - & - \\
\hline & OG & 358 & $\leq 6 n=239 ;>6 n=119$ & - & - & - & 83 & 275 & - & - & - & - & - & - & - & - & - \\
\hline \multirow{2}{*}{$\begin{array}{l}\text { Cormedi } \\
\text { et al. (5) }\end{array}$} & $Y G$ & 71 & - & - & - & - & - & - & - & - & 3 & 57 & 3 & - & - & - & - \\
\hline & OG & 223 & - & - & - & - & - & - & - & - & 78 & 74 & 14 & - & - & - & - \\
\hline Tavares & $Y G$ & 23 & - & 12 & 3 & - & 4 & 12 & - & - & 8 & 15 & 0 & - & - & - & - \\
\hline & OG & 360 & - & 160 & 100 & - & 56 & 89 & - & - & 255 & 105 & 0 & - & - & - & - \\
\hline Guan & $Y G$ & 1,369 & $5.00 \pm 3.00$ & - & - & - & 31 & 916 & 558 & 25 & 668 & 652 & - & - & - & - & - \\
\hline et al. (9) & OG & 46,521 & $4.00 \pm 1.47$ & - & - & - & 2493 & 22,616 & 5756 & 990 & 37,799 & 7,021 & - & - & - & - & - \\
\hline Isobe & $Y G$ & 169 & - & - & - & - & - & 66 & 75 & 4 & - & - & - & - & - & - & - \\
\hline et al. (10) & $O G$ & 3,649 & - & - & - & - & - & 943 & 600 & 82 & - & - & - & - & - & - & - \\
\hline Kim & $Y G$ & 137 & $5.07 \pm 3.23$ & - & - & - & - & - & 25 & 4 & - & - & - & 5 & 13 & 93 & 26 \\
\hline et al. (11) & OG & 194 & $5.16 \pm 3.45$ & - & - & - & - & - & 6 & 10 & - & - & - & 10 & 43 & 128 & 13 \\
\hline Kunisaki & $Y G$ & 131 & $<5 n=76 ; \geq 5 n=55$ & - & - & - & 30 & 101 & - & - & - & - & - & - & - & - & - \\
\hline et al. (12) & OG & 918 & $<5 n=536 ; \geq 5 n=382$ & - & - & - & 479 & 439 & - & - & - & - & - & - & - & - & - \\
\hline Liu & YG & 198 & - & - & - & 0 & 7 & 164 & - & - & - & - & - & - & - & - & - \\
\hline et al. (13) & OG & 1,096 & - & - & - & 29 & 123 & 587 & - & - & - & - & - & - & - & - & - \\
\hline Okamoto & $Y G$ & 34 & - & - & - & - & - & 22 & 2 & 0 & - & - & - & $0 / 20$ & 0 & 12 & 4 \\
\hline et al. (14) & OG & 132 & - & - & - & - & - & 51 & 1 & 5 & - & - & - & $3 / 85$ & 25 & 34 & 14 \\
\hline Takatsu & $Y G$ & 136 & - & - & - & - & 13 & 123 & - & - & - & - & - & - & - & - & - \\
\hline et al. (15) & OG & 1,435 & - & - & - & - & 662 & 773 & - & - & - & - & - & - & - & - & - \\
\hline Tekesin & YG & 92 & - & 22 & 6 & - & - & - & - & - & 39 & 45 & 7 & - & - & - & - \\
\hline et al. (16) & $\mathrm{OG}$ & 774 & - & 191 & 52 & - & - & - & - & - & 526 & 220 & 21 & - & - & - & - \\
\hline Wang & $Y G$ & 21 & $<5 n=13 ; \geq 5 n=8$ & - & - & - & 4 & 10 & 4 & 1 & - & - & - & 1 & 6 & 12 & 2 \\
\hline et al. (16) & $O G$ & 36 & $<5 n=23 ; \geq 5 n=13$ & - & - & - & 10 & 4 & 2 & 5 & - & - & - & 2 & 13 & 19 & 1 \\
\hline Hsieh & $Y G$ & 115 & $4.80 \pm 3.50$ & - & - & - & 17 & 98 & - & - & 17 & 64 & 13 & - & - & - & - \\
\hline et al. (18) & OG & 1,009 & $4.50 \pm 3.00$ & - & - & - & 453 & 556 & - & - & 491 & 279 & 103 & - & - & - & - \\
\hline $\mathrm{Ma}$ & $Y G$ & 125 & - & - & - & - & 3 & 111 & - & - & - & - & - & - & - & - & - \\
\hline etal. (IY) & $O G$ & 1,752 & - & - & - & - & 93 & 1,228 & - & - & - & - & - & - & - & - & - \\
\hline Mitsudomi & YG & 128 & - & 48 & 6 & 3 & 5 & 94 & - & - & - & - & - & 2 & 11 & 28 & 20 \\
\hline et al. (20) & OG & 1,275 & - & 20 & 3 & 14 & 600 & 449 & - & - & - & - & - & 20 & 175 & 347 & 106 \\
\hline Kulig & $Y G$ & 214 & - & 90 & 12 & 2 & - & - & - & - & 42 & 80 & 18 & - & - & - & - \\
\hline et al. (21) & $O G$ & 3,217 & - & 1831 & 186 & 293 & - & - & - & - & 1,106 & 623 & 207 & - & - & - & - \\
\hline Bani-Hani & $Y G$ & 17 & - & 12 & 2 & - & - & 8 & - & - & 6 & 11 & - & - & - & - & - \\
\hline et al. (22) & $\mathrm{OG}$ & 159 & - & 109 & 23 & - & - & 41 & - & - & 121 & 18 & - & - & - & - & - \\
\hline & $Y G$ & 175 & - & - & - & - & 42 & 133 & - & - & - & - & - & - & - & - & - \\
\hline et al. (23) & OG & 1,124 & - & - & - & - & 608 & 516 & - & - & - & - & - & - & - & - & - \\
\hline Lai & YG & 883 & $\leq 4 n=586 ;>4 n=288$ & - & - & - & 135 & 711 & - & - & - & - & - & 10 & 114 & 297 & 75 \\
\hline et al. (24) & OG & 6,071 & $\leq 4 n=354 ;>4 n=2,488$ & - & - & - & 2,661 & 3,232 & - & - & - & - & - & 665 & 812 & 2,039 & 405 \\
\hline Maehara & YG & 174 & $7.10 \pm 4.20$ & - & - & - & 39 & 135 & - & - & - & - & - & - & - & - & - \\
\hline et al. (2b) & $\mathrm{OG}$ & 356 & $6.30 \pm 3.80$ & - & - & - & 225 & 129 & - & - & - & - & - & - & - & - & - \\
\hline Silva & $Y G$ & 62 & $\leq 5 n=31 ;>5 n=27$ & - & - & - & - & - & - & - & 15 & 36 & 11 & - & - & - & - \\
\hline et al. (26) & $\mathrm{OG}$ & 453 & $\leq 5 n=179 ;>5 n=259$ & - & - & - & - & - & - & - & 230 & 146 & 77 & - & - & - & - \\
\hline Zhou & $Y G$ & 152 & - & 73 & 19 & - & - & - & - & - & 14 & 120 & 18 & - & - & - & - \\
\hline$e$ & $O G$ & 250 & - & 98 & 11 & - & - & - & - & - & 156 & 73 & 21 & - & - & - & - \\
\hline Adachi & $Y G$ & 36 & 6 & 23 & - & 0 & - & 33 & - & - & - & - & - & - & - & - & - \\
\hline (28) & $O G$ & 68 & 6.05 & 16 & - & 21 & - & 35 & - & - & - & - & - & - & - & - & - \\
\hline Bautista & YG & 46 & - & - & - & 3 & 0 & 37 & - & - & 14 & 32 & - & - & - & - & - \\
\hline et al. (29) & $O G$ & 1,208 & - & - & - & 564 & 40 & 759 & - & - & 754 & 494 & - & - & - & - & - \\
\hline Wang & $Y G$ & 342 & - & - & - & - & 16 & 258 & 86 & 16 & 64 & 166 & 112 & 18 & 114 & 156 & 54 \\
\hline et al. (30) & OG & 3,588 & - & - & - & - & 172 & 2,244 & 534 & 233 & 790 & 2,049 & 1,027 & 272 & 1,252 & 1,756 & 308 \\
\hline
\end{tabular}




\begin{tabular}{|c|c|c|c|c|c|c|c|c|c|c|c|}
\hline \multirow[b]{2}{*}{ Study or Subgroup } & \multicolumn{2}{|c|}{ Younger group } & \multicolumn{2}{|c|}{ Older group } & \multirow{2}{*}{ Weight } & \multirow{2}{*}{$\begin{array}{c}\text { Odds Ratio } \\
\text { M-H, Random, } 95 \% \mathrm{Cl}\end{array}$} & \multirow{2}{*}{\multicolumn{3}{|c|}{$\begin{array}{c}\text { Odds Ratio } \\
\text { M-H. Random. } 95 \% \mathrm{Cl}\end{array}$}} & & \\
\hline & Events & Total & Events & Total & & & & & & & \\
\hline Adachi and Ogawa et al 1994 & 16 & 36 & 25 & 68 & $2.1 \%$ & $1.38[0.61,3.13]$ & & & & & \\
\hline Bani 2005 & 10 & 17 & 55 & 159 & $1.5 \%$ & $2.70[0.97,7.49]$ & & & & & \\
\hline Bautista and Jiang et al 2014 & 22 & 46 & 494 & 1208 & $3.1 \%$ & $1.32[0.73,2.39]$ & & & & & \\
\hline Cormedi and Katayama et al 2018 & 37 & 71 & 88 & 223 & $3.4 \%$ & $1.67[0.98,2.86]$ & & & & & \\
\hline Guan and Yuan et al 2019 & 641 & 1369 & 18417 & 46521 & $6.3 \%$ & $1.34[1.21,1.50]$ & & & $\leftarrow$ & & \\
\hline Hsieh and Wang et al 2012 & 69 & 115 & 373 & 1009 & $4.4 \%$ & $2.56[1.72,3.79]$ & & & & & \\
\hline Isobe and Hashimoto et al 2013 & 90 & 169 & 1131 & 3649 & $5.0 \%$ & $2.54[1.86,3.46]$ & & & & & \\
\hline Kim and Boo et al 2008 & 75 & 175 & 359 & 1124 & $4.9 \%$ & $1.60[1.16,2.21]$ & & & & & \\
\hline Kim and Joo et al 2005 & 74 & 137 & 63 & 194 & $4.0 \%$ & $2.44[1.56,3.83]$ & & & & & \\
\hline Kulig and Popiela et al 2008 & 95 & 214 & 940 & 3217 & $5.2 \%$ & $1.93[1.46,2.56]$ & & & & & \\
\hline Kunisaki and Akiyama et al 2006 & 67 & 131 & 260 & 918 & $4.5 \%$ & $2.65[1.83,3.84]$ & & & & & \\
\hline Lai and Kim et al 2008 & 407 & 883 & 1876 & 6071 & $6.1 \%$ & $1.91[1.66,2.21]$ & & & & & \\
\hline Liu and Feng et al 2016 & 83 & 198 & 201 & 1096 & $4.9 \%$ & $3.21[2.33,4.43]$ & & & & & \\
\hline Ma and Ren et al 2018 & 49 & 125 & 411 & 1752 & $4.5 \%$ & $2.10[1.44,3.06]$ & & & & & \\
\hline Maehara and Emi et al1996 & 85 & 174 & 109 & 356 & $4.5 \%$ & $2.16[1.49,3.14]$ & & & & & \\
\hline Mitsudomi and Matsusaka et al 1989 & 62 & 128 & 412 & 1275 & $4.6 \%$ & $1.97[1.36,2.84]$ & & & & & \\
\hline Okamoto and Makino et al 1988 & 24 & 34 & 35 & 132 & $2.0 \%$ & $6.65[2.89,15.30]$ & & & & & \\
\hline Silva and Begnami et al 2008 & 24 & 62 & 165 & 453 & $3.4 \%$ & $1.10[0.64,1.90]$ & & & & & \\
\hline Song and Li et al 2017 & 53 & 112 & 84 & 358 & $4.0 \%$ & $2.93[1.88,4.57]$ & & & & & \\
\hline Takatsu and Hiki et al 2016 & 64 & 136 & 411 & 1435 & $4.6 \%$ & $2.21[1.55,3.16]$ & & & & & \\
\hline Tavares and Gandra et al 2013 & 11 & 23 & 153 & 360 & $2.0 \%$ & $1.24[0.53,2.89]$ & & & & & \\
\hline Tekesin and Gunes et al 2019 & 39 & 92 & 221 & 774 & $4.0 \%$ & $1.84[1.18,2.86]$ & & & & & \\
\hline Wang and Hsieh et al 1996 & 12 & 21 & 14 & 36 & $1.4 \%$ & $2.10[0.70,6.25]$ & & & & & \\
\hline Wang and Xu et al 2016 & 144 & 342 & 1140 & 3588 & $5.6 \%$ & $1.56[1.25,1.96]$ & & & $\rightarrow$ & & \\
\hline Zhou and Shi et al 2015 & 99 & 152 & 72 & 250 & $4.1 \%$ & $4.62[3.00,7.11]$ & & & & & \\
\hline Total $(95 \% \mathrm{Cl})$ & & 4962 & & 76226 & $100.0 \%$ & $2.09[1.81,2.41]$ & & & & & \\
\hline Total events & 2352 & & 27509 & & & & & & & & \\
\hline \multicolumn{7}{|c|}{$\begin{array}{l}\text { Heterogeneity: } \operatorname{Tau}^{2}=0.08 ; \mathrm{Chi}^{2}=99.01, \mathrm{df}=24(\mathrm{P}<0.00001) ; \mathrm{I}^{2}=76 \% \\
\text { Test for overall effect: } Z=10.03(P<0.00001)\end{array}$} & $0.1 \quad 0.2$ & $\begin{array}{c}0.51 \\
\text { Younger }\end{array}$ & Older & 5 & 10 \\
\hline
\end{tabular}

Figure S1 Meta-analysis of female ratio between younger and older group. 
A

Younger group Older group Odds Ratio

\begin{tabular}{|c|c|c|c|c|c|}
\hline Studv or Subgroup & Events & Total & Events & Total & Weight \\
\hline Bani 2005 & 11 & 17 & 18 & 159 & $5.1 \%$ \\
\hline Bautista and Jiang et al 2014 & 32 & 46 & 494 & 1208 & $8.9 \%$ \\
\hline Cormedi and Katayama et al 2018 & 57 & 71 & 74 & 223 & $8.8 \%$ \\
\hline Guan and Yuan et al 2019 & 652 & 1369 & 7021 & 46521 & $14.1 \%$ \\
\hline Hsieh and Wang et al 2012 & 64 & 115 & 279 & 1009 & $11.7 \%$ \\
\hline Kulig and Popiela et al 2008 & 80 & 214 & 623 & 3217 & $12.8 \%$ \\
\hline Silva and Begnami et al 2008 & 36 & 62 & 146 & 453 & $10.0 \%$ \\
\hline Tavares and Gandra et al 2013 & 15 & 23 & 105 & 360 & $6.6 \%$ \\
\hline Tekesin and Gunes et al 2019 & 45 & 92 & 220 & 774 & $11.2 \%$ \\
\hline Zhou and Shi et al 2015 & 120 & 152 & 73 & 250 & $10.7 \%$ \\
\hline Total $(95 \% \mathrm{Cl})$ & & 2161 & & 54174 & $100.0 \%$ \\
\hline Total events & 1112 & & 9053 & & \\
\hline
\end{tabular}

Rand Ratio

$14.36[4.74,43.54]$

$3.30[1.74,6.26]$

$8.20[4.29,15.67]$

$5.12[4.59,5.71]$

$3.28[2.22,4.86]$

$2.49[1.86,3.32]$

$2.91[1.69,5.00]$

$4.55[1.87,11.06]$

$2.41[1.56,3.73]$

$9.09[5.65,14.63]$

$4.29[3.15,5.85]$

Test for overall effect: $Z=9.20$ ( $P<0.00001$ )

B

Study or Subgroup

Younger group Older group

Adachi and Ogawa et al 1994

Bani 2005

Cormedi and Katayama et al 2018

Hsieh and Wang et al 2012

Isobe and Hashimoto et al 2013

Kim and Boo et al 2008

Kim and Joo et al 2005

Kulig and Popiela et al 2008

Kunisaki and Akiyama et al 2006

Lai and Kim et al 2008

Song and Li et al 2017

Takatsu and Hiki et al 2016

Tavares and Gandra et al 2013

Tekesin and Gunes et al 2019

Wang and $X u$ et al 2016

Zhou and Shi et al 2015

Odds Ratio

Odds Ratio

M-H. Random, $95 \% \mathrm{Cl}$

Total $(95 \% \mathrm{Cl})$

$\begin{array}{llll}\text { Total events } & 493 & 2805 & 3754\end{array}$

$\begin{array}{rr}7 & 36 \\ 7 & 17 \\ 36 & 71\end{array}$

Events Total Weight

Fixed, $95 \%$ C

$\begin{array}{lllllll}36 & 71 & 89 & 223 & 3.9 \% & 1.55[0.91,2.65]\end{array}$

$\begin{array}{llllll}14 & 115 & 89 & 1009 & 2.9 \% & 1.43[0.79,2.61]\end{array}$

$\begin{array}{llllll}48 & 169 & 782 & 3649 & 9.1 \% & 1.45[1.03,2.05]\end{array}$

$\begin{array}{llllll}37 & 175 & 236 & 1124 & 9.2 \% & 1.01\end{array}[0.68,1.49]$

$\begin{array}{llllll}39 & 137 & 38 & 194 & 4.1 \% & 1.63[0.98,2.73]\end{array}$

$\begin{array}{llllll}63 & 214 & 770 & 3217 & 12.4 \% & 1.33[0.98,1.80]\end{array}$

$\begin{array}{llllll}12 & 131 & 111 & 918 & 4.6 \% & 0.73[0.39,1.37]\end{array}$

$\begin{array}{llllll}91 & 883 & 597 & 6071 & 25.0 \% & 1.05\end{array}[0.83,1.33]$

$\begin{array}{llllll}18 & 112 & 38 & 358 & 2.8 \% & 1.61[0.88,2.96]\end{array}$

$\begin{array}{llrrrr}22 & 136 & 190 & 1435 & 5.1 \% & 1.26[0.78,2.05]\end{array}$

$\begin{array}{llllll}6 & 23 & 97 & 360 & 1.6 \% & 0.96[0.37,2.50]\end{array}$

$\begin{array}{llllll}52 & 92 & 372 & 774 & 6.3 \% & 1.40[0.91,2.17\end{array}$

$\begin{array}{llllll}26 & 342 & 263 & 3588 & 7.8 \% & 1.04[0.68,1.58]\end{array}$

$\begin{array}{llllll}15 & 152 & 22 & 250 & 2.8 \% & 1.13[0.57,2.26]\end{array}$

Heterogeneity: $\mathrm{Ch}^{2}=11.34, \mathrm{df}=15(\mathrm{P}=0.73) ; \mathrm{I}^{2}=0 \%$

Test for overall effect: $Z=3.40(P=0.0007)$

C

Study or Subqroup

Adachi and Ogawa et al 1994

Bani 2005

Bautista and Jiang et al 2014

Guan and Yuan et al 2019

Hsieh and Wang et al 2012

Isobe and Hashimoto et al 2013

Kim and Boo et al 2008

Kunisaki and Akiyama et al 2006

Lai and Kim et al 2008

Liu and Feng et al 2016

Ma and Ren et al 2018

Maehara and Emi et al1996

Mitsudomi and Matsusaka et al 1989

Okamoto and Makino et al 1988

Song and Li et al 2017

Takatsu and Hiki et al 2016

Tavares and Gandra et al 2013

Wang and Hsieh et al 199

Wang and $X u$ et al 2016

Younger group Older group

$23397 \quad 100.0 \%$

$1.21[1.08,1.35]$

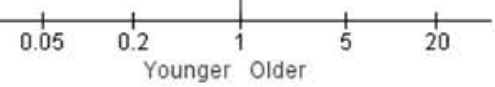

M-H. Fixed, $95 \% \mathrm{Cl}$

\section{Total $(95 \% \mathrm{Cl})$}

Total events

Events Total Events Total Weight

Odds Ratio

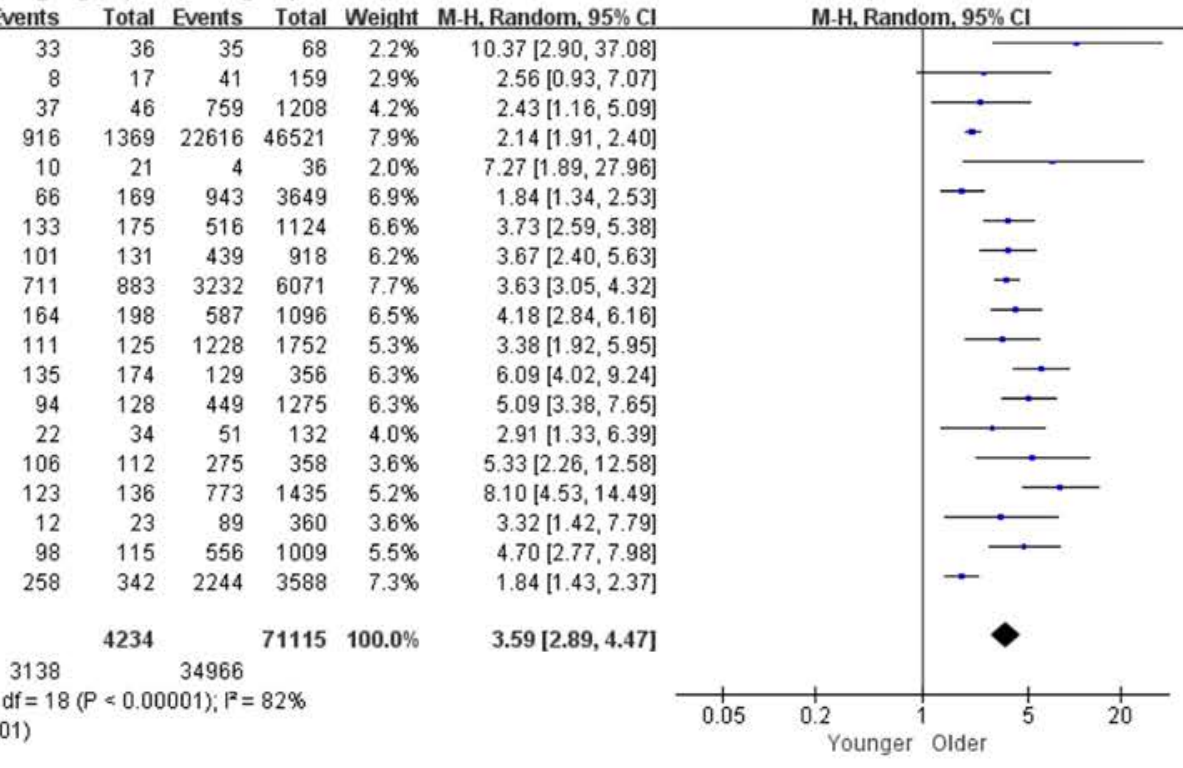

Heterogeneity. Tau $^{2}=0.15 ; \mathrm{Chi}^{2}=102.79, \mathrm{df}=18(\mathrm{P}<0.00001) ; \mathrm{F}^{2}=82 \%$

Test for overall effect: $Z=11.46(P<0.00001)$

D

Study or Subgroup

Younger group Older group Odds Ratio

Guan and Yuan et al 2019

Isobe and Hashimoto et al 2013

Kim and Joo et al 2005

Okamoto and Makino et al 1988

Wang and Hsieh et al 1996

Events

$\begin{array}{lllllll}558 & 1369 & 5756 & 46521 & 84.7 \% & 4.87[4.36,5.45]\end{array}$

$\begin{array}{llllll}75 & 169 & 600 & 3649 & 12.8 \% & 4.05[2.96,5.56]\end{array}$

$\begin{array}{llllll}25 & 137 & 6 & 194 & 1.8 \% & 6.99[2.78,17.57]\end{array}$

$\begin{array}{lllllll}2 & 34 & 1 & 132 & 0.2 \% & 8.19[0.72,93.13]\end{array}$

$\left.\begin{array}{llllll}4 & 21 & 2 & 36 & 0.5 \% & 4.00[0.66,24.06\end{array}\right]$

Total $(95 \% \mathrm{CI})$

1730

Total events

$1730 \quad 50532 \quad 100.0 \%$

$4.81[4.33,5.33]$

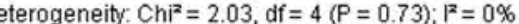

Test for overall effect: $Z=29.52(P<0.00001)$ 6365

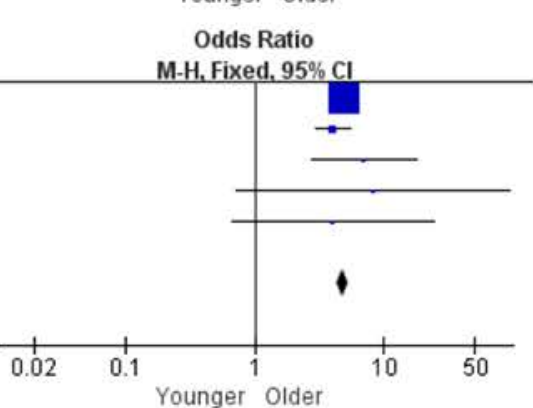

Figure S2 The proportion of clinicopathologic feature between younger and older group. (A) Meta-analysis of diffuse type; (B) metaanalysis of pTNM stage IV; (C) meta-analysis of poorly differentiation; (D) meta-analysis of signet ring cell carcinoma. 


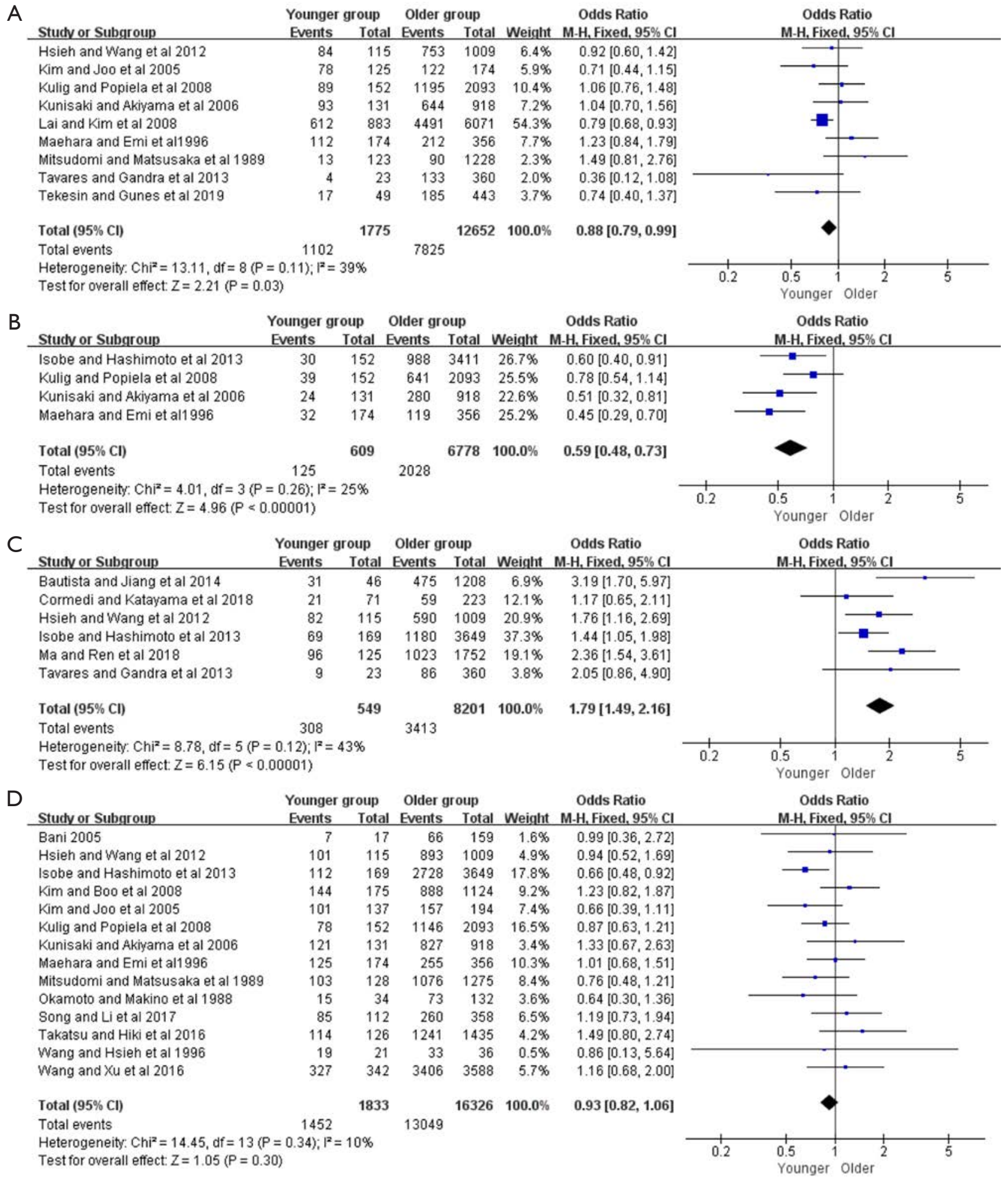

Figure S3 The proportion of therapeutic regimen between younger and older group. (A) Meta-analysis of subtotal gastrectomy; (B) metaanalysis of D1 lymphadenectomy; (C) meta-analysis of chemotherapy; (D) meta-analysis of curative resection. 


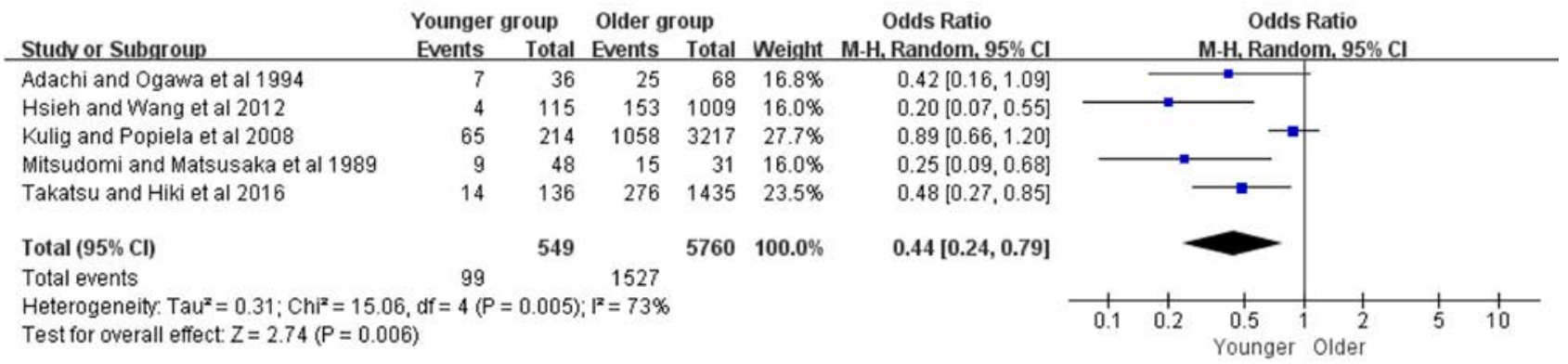

Figure S4 Meta-analysis of the proportion of postoperative complications between younger and older group. 
Table S2 Subgroup meta-analysis of overall survival comparison between the younger group and older group

\begin{tabular}{|c|c|c|c|c|c|c|c|}
\hline Subgroup & $\begin{array}{l}\text { Included } \\
\text { studies }\end{array}$ & $\begin{array}{l}\text { Included } \\
\text { patients }\end{array}$ & $\mathrm{I}^{2}(\%)$ & Effect model & OR/WMD & $95 \% \mathrm{Cl}$ & $P$ \\
\hline \multicolumn{8}{|l|}{ OS } \\
\hline 1-year OS & 8 & 59,132 & 81 & Random & 1.08 & $0.80-1.45$ & 0.63 \\
\hline 2-year OS & 8 & 59,132 & 78 & Random & 1.04 & $0.79-1.36$ & 0.79 \\
\hline 3-year OS & 8 & 59,132 & 74 & Random & 1.01 & $0.78-1.32$ & 0.93 \\
\hline 5-year OS & 9 & 59,647 & 60 & Random & 1.01 & $0.79-1.30$ & 0.92 \\
\hline \multicolumn{8}{|c|}{ OS underwent gastrectomy } \\
\hline 1-year OS & 15 & 18,442 & 0 & Fixed & 1.20 & $1.04-1.39$ & 0.01 \\
\hline 2-year OS & 15 & 18,442 & 56 & Random & 1.31 & $1.08-1.58$ & 0.005 \\
\hline 3-year OS & 15 & 18,442 & 1 & Fixed & 1.33 & $1.19-1.48$ & $<0.001$ \\
\hline 5-year OS & 18 & 26,770 & 56 & Random & 1.35 & $1.16-1.57$ & $<0.001$ \\
\hline \multicolumn{8}{|c|}{ Stage I-OS underwent gastrectomy ${ }^{1}$} \\
\hline 1-year OS & 5 & 5,437 & 0 & Fixed & 5.18 & $1.03-26.03$ & 0.05 \\
\hline 2-year OS & 5 & 5,437 & 0 & Fixed & 2.29 & $1.11-4.71$ & 0.02 \\
\hline 3-year OS & 5 & 5,437 & 0 & Fixed & 3.32 & $1.72-6.40$ & $<0.001$ \\
\hline 5-year OS & 8 & 6,536 & 11 & Fixed & 2.38 & $1.56-3.61$ & $<0.001$ \\
\hline \multicolumn{8}{|c|}{ Stage II-OS underwent gastrectomy } \\
\hline 1-year OS & 5 & 2,735 & 0 & Fixed & 1.54 & $0.72-3.33$ & 0.27 \\
\hline 2-year OS & 5 & 2,735 & 0 & Fixed & 1.25 & $0.80-1.94$ & 0.33 \\
\hline 3-year OS & 5 & 2,735 & 45 & Fixed & 1.47 & $1.01-2.14$ & 0.04 \\
\hline 5-year OS & 8 & 3,347 & 46 & Fixed & 1.28 & $0.98-1.66$ & 0.07 \\
\hline \multicolumn{8}{|c|}{ Stage III-OS underwent gastrectomy } \\
\hline 1-year OS & 5 & 4,499 & 61 & Random & 1.41 & $0.81-2.45$ & 0.22 \\
\hline 2-year OS & 5 & 4,499 & 55 & Random & 1.53 & $1.07-2.20$ & 0.02 \\
\hline 3-year OS & 5 & 4,499 & 60 & Random & 1.62 & $1.14-2.31$ & 0.007 \\
\hline 5-year OS & 7 & 5,702 & 27 & Fixed & 1.36 & $1.14-1.63$ & $<0.001$ \\
\hline \multicolumn{8}{|c|}{ Stage IV-OS underwent gastrectomy } \\
\hline 1-year OS & 5 & 1,341 & 74 & Random & 1.18 & $0.54-2.58$ & 0.68 \\
\hline 2-year OS & 5 & 1,341 & 83 & Random & 3.46 & $1.26-9.56$ & 0.02 \\
\hline 3-year OS & 5 & 1,341 & 41 & Fixed & 1.77 & $1.23-2.54$ & 0.002 \\
\hline 5-year OS & 7 & 1,483 & 0 & Fixed & 1.93 & $1.30-2.85$ & 0.001 \\
\hline \multicolumn{8}{|c|}{ OS underwent curative surgery } \\
\hline 1-year OS & 11 & 12,660 & 0 & Fixed & 1.35 & $1.05-1.72$ & 0.02 \\
\hline 2-year OS & 11 & 12,660 & 33 & Fixed & 1.22 & $1.03-1.45$ & 0.02 \\
\hline 3-year OS & 11 & 12,660 & 0 & Fixed & 1.36 & $1.17-1.58$ & $<0.001$ \\
\hline 5-year OS & 12 & 19,012 & 60 & Random & 1.39 & $1.12-1.72$ & 0.002 \\
\hline \multicolumn{8}{|c|}{ Stage I-OS underwent curative surgery } \\
\hline 5-year OS & 4 & 5,261 & 51 & Random & 1.73 & $0.86-3.49$ & 0.13 \\
\hline \multicolumn{8}{|c|}{ Stage II-OS underwent curative surgery } \\
\hline 5-year OS & 4 & 2,771 & 51 & Random & 1.07 & $0.80-1.43$ & 0.67 \\
\hline \multicolumn{8}{|c|}{ Stage III-OS underwent curative surgery } \\
\hline 5-year OS & 4 & 4,639 & 0 & Fixed & 1.29 & $1.05-1.58$ & 0.01 \\
\hline \multicolumn{8}{|c|}{ Stage IV-OS underwent curative surgery } \\
\hline 5-year OS & 3 & 1,016 & 0 & Fixed & 1.86 & $1.20-2.89$ & 0.006 \\
\hline \multicolumn{8}{|c|}{ OS underwent Non-curative surgery } \\
\hline 1-year OS & 3 & 268 & 70 & Random & 1.31 & $0.40-4.29$ & 0.66 \\
\hline 2-year OS & 3 & 268 & 38 & Fixed & 0.92 & $0.49-1.71$ & 0.87 \\
\hline 3-year OS & 3 & 268 & 0 & Fixed & 1.37 & $0.72-2.61$ & 0.34 \\
\hline 5-year OS & 3 & 268 & 0 & Fixed & 1.14 & $0.56-2.36$ & 0.72 \\
\hline
\end{tabular}

${ }^{1}$ stage, pTNM stage. OS, overall survival. 
A

\begin{tabular}{|c|c|c|c|c|c|c|c|c|c|c|c|}
\hline \multirow[b]{2}{*}{ Study or Subgroup } & \multicolumn{2}{|c|}{ Younger group } & \multicolumn{2}{|c|}{ Older group } & \multicolumn{2}{|r|}{ Odds Ratio } & \multicolumn{5}{|c|}{ Odds Ratio } \\
\hline & \multicolumn{2}{|l|}{ Events } & Events & Total & Weight & M-H, Fixed. $95 \% \mathrm{Cl}$ & \multicolumn{5}{|c|}{ M-H. Fixed, $95 \% \mathrm{Cl}$} \\
\hline Kunisaki and Akiyama et al 2006 & 18 & 131 & 61 & 918 & $40.9 \%$ & $2.24[1.28,3.92]$ & & & ב- & & \\
\hline Maehara and Emi et al1996 & 15 & 125 & 25 & 255 & $45.1 \%$ & $1.25[0.64,2.47]$ & & & & & \\
\hline Takatsu and Hiki et al 2016 & 6 & 14 & 58 & 276 & $10.0 \%$ & $2.82[0.94,8.45]$ & & & & & \\
\hline Tavares and Gandra et al 2013 & 3 & 19 & 10 & 227 & $4.1 \%$ & $4.07[1.02,16.28]$ & & & & & \\
\hline Total $(95 \% \mathrm{Cl})$ & & 289 & & 1676 & $100.0 \%$ & $1.93[1.31,2.84]$ & & & & & \\
\hline Total events & 42 & & 154 & & & & & & & & \\
\hline $\begin{array}{l}\text { Heterogeneity: } \mathrm{Chi}^{2}=3.38, \mathrm{df}=3 \\
\text { Test for overall effect: } \mathrm{Z}=3.30 \text { (P }\end{array}$ & $\begin{array}{l}=0.34) ; 1^{2} \\
(.0010)\end{array}$ & $1 \%$ & & & & & $0.1 \quad 0.2$ & 0.5 & 1 & 5 & 10 \\
\hline
\end{tabular}

B

\section{Study or Subgroup}

Younger group Older group

Odds Ratio

Odds Ratio

Adachi and Ogawa et al 1994

Hsieh and Wang et al 2012

Isobe and Hashimoto et al 2013 Events Total Events Total Weight M-H. Random. 95\% Cl

Kim and Joo et al 2005

Kunisaki and Akiyama et al 2006

Maehara and Emi et al1996

Okamoto and Makino et al 1988

Tekesin and Gunes et al 2019

Wang and $X u$ et al 2016

$\begin{array}{rrrrr}4 & 7 & 7 & 24 & 3.1 \\ 76 & 115 & 461 & 1009 & 15.2 \\ 33 & 169 & 414 & 3649 & 15.4 \\ 21 & 137 & 18 & 194 & 11.0 \\ 6 & 131 & 44 & 918 & 8.4 \\ 23 & 125 & 23 & 255 & 11.7 \\ 13 & 34 & 20 & 132 & 8.8 \\ 26 & 92 & 230 & 774 & 14.0 \\ 13 & 342 & 173 & 3588 & 12.4 \\ & & & & \\ & 1152 & & & \\ 215 & & 139053 & \mathbf{1 0 0 . 0}\end{array}$

Total $(95 \% \mathrm{CI})$

Total events

215 1390

Heterogeneity. Tau $^{2}=0.15 ; \mathrm{Chi}^{2}=21.36, \mathrm{df}=8(P=0.006) ; \mathrm{I}^{2}=63 \%$

Test for overall effect: $Z=2.85(P=0.004)$

C

Studv or Subgroup

Adachi and Ogawa et al 1994

Kim and Boo et al 2008

Kim and Joo et al 2005

Kunisaki and Akiyama et al 2006

Maehara and Emi et al1996

Okamoto and Makino et al 1988

Silva and Begnami et al 2008

Wang and Hsieh et al 1996

Younger group Older group

$3.24[0.57,18.38]$

$2.32[1.54,3.47]$

$1.90[1.28,2.81]$

$1.77[0.90,3.47]$

$0.95[0.40,2.28]$

$2.27[1.22,4.24]$

$3.47[1.50,8.03]$

$0.93[0.58,1.50]$

$0.78[0.44,1.39]$

$1.63[1.16,2.27]$

Odds Ratio
H. Fixed, 95\%

$\begin{array}{llrrrr}17 & 36 & 33 & 68 & 4.3 \% & 0.95[0.42,2.13\end{array}$

$\begin{array}{llllll}86 & 175 & 566 & 1124 & 27.8 \% & 0.95[0.69,1.31]\end{array}$

$\begin{array}{lllllll}70 & 137 & 106 & 194 & 15.4 \% & 0.87[0.56,1.34]\end{array}$

$\begin{array}{llllll}48 & 131 & 397 & 918 & 22.5 \% & 0.76[0.52,1.11]\end{array}$

$\begin{array}{llllll}95 & 125 & 207 & 255 & 11.7 \% & 0.73[0.44,1.23]\end{array}$

$\begin{array}{llllll}19 & 34 & 64 & 132 & 4.1 \% & 1.35[0.63,2.87]\end{array}$

$\begin{array}{llllll}38 & 62 & 342 & 453 & 11.4 \% & 0.51[0.30,0.89]\end{array}$

$\begin{array}{rrrrrr}12 & 21 & 25 & 36 & 2.8 \% & 0.59[0.19,1.79]\end{array}$

Total $(95 \% \mathrm{Cl})$

$\begin{array}{lll}721 & 3180 & 100.0 \%\end{array}$

$0.83[0.69,0.98]$

Total events $\quad 385 \quad 1740$

Heterogeneity. $\mathrm{Chi}^{2}=6.09, \mathrm{df}=7(\mathrm{P}=0.53) ; \mathrm{I}^{2}=0 \%$

Test for overall effect: $Z=2.15(P=0.03)$

D

\section{Studv or Subgroup}

Younger group Older group

Odds Ratio

Adachi and Ogawa et al 1994

Isobe and Hashimoto et al 2013

Kim and Joo et al 2005

Kunisaki and Akiyama et al 2006

Maehara and Emi et al1996

Okamoto and Makino et al 1988

Takatsu and Hiki et al 2016

Tavares and Gandra et al 2013

Wang and Xu et al 2016

Events

Total Events Tota

- H. Fixed, 95\% Cl

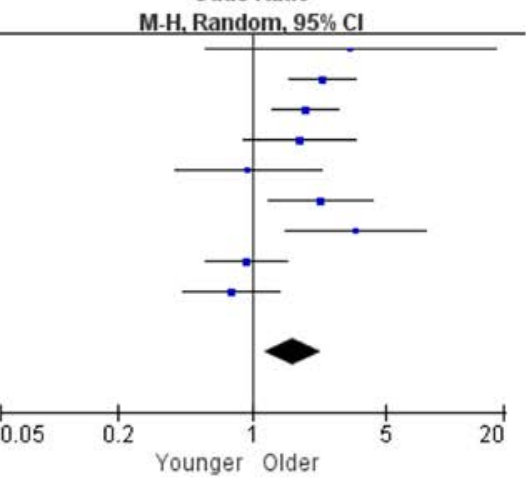

$\begin{array}{llllll}1 & 7 & 3 & 24 & 1.5 \% & 1.17[0.10,13.36]\end{array}$

$\begin{array}{llllll}4 & 169 & 203 & 3469 & 23.0 \% & 0.39[0.14,1.06]\end{array}$

$\begin{array}{llllll}5 & 137 & 6 & 194 & 6.0 \% & 1.19[0.35,3.97]\end{array}$

$\begin{array}{lllll}2 & 131 & 22 & 918 & 6.8 \%\end{array}$

$\begin{array}{lllll}2 & 125 & 16 & 255 & 13.0 \%\end{array}$

$\begin{array}{llllr}2 & 34 & 10 & 132 & 4.8 \%\end{array}$

$\begin{array}{rrrrr}2 & 34 & 10 & 132 & 4.8 \% \\ 1 & 114 & 33 & 1241 & 6.9 \%\end{array}$

$\begin{array}{rrrrr}1 & 19 & 21 & 227 & 3.8 \%\end{array}$

$\begin{array}{rr}16 & 342\end{array}$

$165 \quad 3588 \quad 34.2 \%$

$0.63[0.15,2.72]$

$0.24[0.05,1.07]$

$0.76[0.16,3.66]$

$0.32[0.04,2.39]$

$0.54[0.07,4.29]$

$1.02[0.60,1.72]$

Total $(95 \% \mathrm{Cl})$

1078

$10048100.0 \%$

Total events $\quad 34 \quad 479$

Heterogeneity: $\mathrm{Chi}^{2}=6.90, \mathrm{df}=8(P=0.55) ; \mathrm{I}^{2}=0 \%$

$0.68[0.47,0.98]$

Test for overall effect: $Z=2.07(P=0.04)$

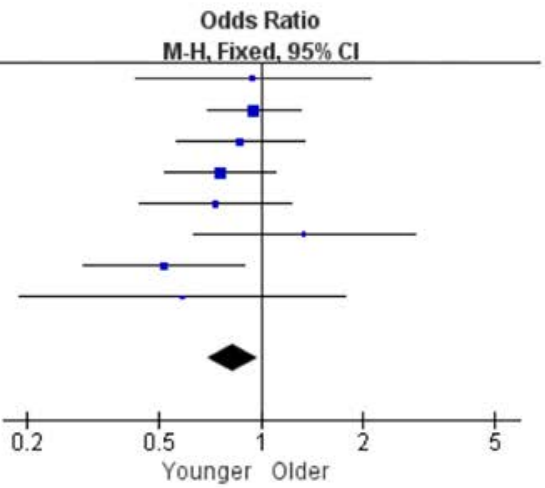

Odds Ratio

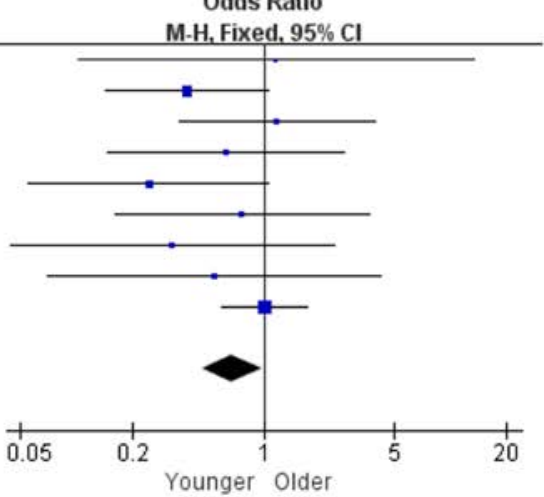

Figure S5 The proportion of metastasis and recurrence between younger and older group. (A) Meta-analysis of peritoneal recurrence; (B) meta-analysis of peritoneal metastasis; (C) meta-analysis of lymph node metastasis; (D) meta-analysis of hepatic metastasis. 
Table S3 Therapeutic regimens and survival outcomes of the included studies

\begin{tabular}{|c|c|c|c|c|c|c|c|c|c|c|c|c|c|c|c|c|}
\hline \multirow{2}{*}{ Authors } & \multirow{2}{*}{ Group } & \multirow{2}{*}{ No. } & \multicolumn{2}{|c|}{ Type of gastrectomy } & \multicolumn{2}{|c|}{ Resection margin } & \multicolumn{3}{|c|}{ Lymphadenectomy } & \multirow{2}{*}{ Chemotherapy } & \multirow{2}{*}{ Complication } & \multirow{2}{*}{$\begin{array}{l}\text { Peritoneal } \\
\text { recurrence }\end{array}$} & \multicolumn{4}{|c|}{ Metastasis } \\
\hline & & & Subtotal & Total & Ro & $\mathrm{R} 1 / \mathrm{R} 2$ & Do & D1 & $\geq \mathrm{D} 2$ & & & & Lymph node & Vessel & Hepatic & Peritoneal \\
\hline \multirow[t]{2}{*}{ Song et al. (4) } & $Y G$ & 112 & - & - & 85 & 27 & - & - & - & - & - & - & - & - & - & - \\
\hline & OG & 358 & - & - & 260 & 98 & - & - & - & - & - & - & - & - & - & - \\
\hline \multirow[t]{2}{*}{ Cormedi et al. (5) } & $Y G$ & 71 & - & - & - & - & - & - & - & 21 & - & - & - & - & - & - \\
\hline & OG & 223 & - & - & - & - & - & - & - & 59 & - & - & - & - & - & - \\
\hline \multirow[t]{2}{*}{ Tavares et al. (8) } & $Y G$ & 23 & 4 & 19 & - & - & - & - & - & 9 & - & 3 & - & - & 1 & - \\
\hline & $\mathrm{OG}$ & 360 & 133 & 227 & - & - & - & - & - & 86 & - & 10 & - & - & 21 & - \\
\hline \multirow[t]{2}{*}{ Guan et al. (9) } & $Y G$ & 1,349 & - & - & - & - & - & - & - & - & - & - & - & - & - & - \\
\hline & OG & 46,521 & - & - & - & - & - & - & - & - & - & - & - & - & - & - \\
\hline \multirow[t]{2}{*}{ Isobe et al. (10) } & $Y G$ & 169 & - & 52 & 112 & - & 3 & 30 & 119 & 69 & - & - & - & - & 4 & 33 \\
\hline & OG & 3,649 & - & 936 & 2,728 & - & 217 & 988 & 2,205 & 1,180 & - & - & - & - & 203 & 414 \\
\hline \multirow[t]{2}{*}{ Kim et al. (11) } & $Y G$ & 137 & 78 & 47 & 101 & - & - & - & - & - & - & - & 70 & - & 5 & 21 \\
\hline & OG & 194 & 122 & 52 & 157 & - & - & - & - & - & - & - & 106 & - & 6 & 18 \\
\hline Kunisaki et al. (12) & $Y G$ & 131 & 93 & 25 & 121 & - & - & 24 & 107 & - & - & 18 & 48 & 34 & 2 & 6 \\
\hline & OG & 918 & 644 & 274 & 827 & - & - & 280 & 638 & - & - & 61 & 397 & 332 & 22 & 44 \\
\hline Liu et al. (13) & $Y G$ & - & - & - & - & - & - & - & - & - & - & - & - & - & - & - \\
\hline & OG & - & - & - & - & - & - & - & - & - & - & - & - & - & - & - \\
\hline Okamoto et al. (14) & $Y G$ & 34 & - & - & 15 & - & 10 & - & - & - & - & - & 19 & - & 2 & 13 \\
\hline & OG & 132 & - & - & 73 & - & 23 & - & - & - & - & - & 64 & - & 10 & 20 \\
\hline Takatsu et al. (15) & $Y G$ & 126 & - & 32 & 114 & 22 & - & - & - & - & 14 & 6 & - & - & $1 / 114$ & - \\
\hline & OG & 1,435 & - & 445 & 1,241 & 194 & - & - & - & - & 276 & 58 & - & - & $33 / 1,241$ & - \\
\hline Tekesin et al. (16) & $Y G$ & 92 & 17 & 32 & - & - & - & - & - & - & - & - & - & 29 & - & 26 \\
\hline & $O G$ & 774 & 185 & 260 & - & - & - & - & - & - & - & - & - & 254 & - & 230 \\
\hline Wang et al. (17) & $Y G$ & 21 & - & - & 19 & - & - & - & - & - & 4 & - & - & 20 & - & 76 \\
\hline & OG & 36 & - & - & 33 & - & - & - & - & - & 153 & - & - & 155 & - & 461 \\
\hline Hsieh et al. (18) & $Y G$ & 115 & 84 & 31 & 101 & 14 & - & - & - & 82 & - & - & 12 & - & - & - \\
\hline & OG & 1,009 & 753 & 256 & 893 & 116 & - & - & - & 590 & - & - & 25 & - & - & - \\
\hline Ma et al. (19) & $Y G$ & 125 & - & - & - & - & - & - & - & 96 & - & - & - & 43 & - & - \\
\hline & OG & 1,752 & - & - & - & - & - & - & - & 1,023 & - & - & - & 451 & - & - \\
\hline Mitsudomi et al. (20) & $Y G$ & 128 & 13 & 29 & 103 & - & - & - & - & - & 9 & - & - & - & - & - \\
\hline & OG & 1,275 & 90 & 236 & 1,076 & - & - & - & - & - & 15 & - & - & - & - & - \\
\hline Kulig et al. (21) & $Y G$ & 214 & 89 & 63 & 78 & 74 & - & 39 & 113 & - & 65 & - & - & - & - & - \\
\hline & OG & 3,217 & 1,195 & 898 & 1,146 & 947 & - & 641 & 1,452 & - & 1,058 & - & - & - & - & - \\
\hline Bani-Hani et al. (22) & $Y G$ & 17 & - & - & 7 & - & - & - & - & - & - & - & - & - & - & - \\
\hline & $\mathrm{OG}$ & 159 & - & - & 66 & - & - & - & - & - & - & - & - & - & - & - \\
\hline Kim et al. (23) & $Y G$ & 175 & - & - & 144 & 31 & - & - & - & - & - & - & 86 & - & - & - \\
\hline & OG & 1,124 & - & - & 888 & 236 & - & - & - & - & - & - & 566 & - & - & - \\
\hline Lai et al. (24) & $Y G$ & 883 & 612 & 262 & - & - & - & - & - & - & - & - & - & - & - & - \\
\hline & $O G$ & 6,071 & 4,491 & 1,519 & - & - & - & - & - & - & - & - & - & - & - & - \\
\hline Maehara et al. (25) & $Y G$ & 174 & 112 & 62 & 125 & - & - & 32 & 141 & - & - & 15 & 95 & 15 & 2 & 23 \\
\hline & OG & 356 & 212 & 139 & 255 & - & - & 119 & 237 & - & - & 25 & 207 & 81 & 16 & 23 \\
\hline Silva et al. (26) & $Y G$ & - & - & - & - & - & - & - & - & - & - & - & 38 & - & - & - \\
\hline & $O G$ & - & - & - & - & - & - & - & - & - & - & - & 342 & - & - & - \\
\hline Adachi et al. (28) & $Y G^{2}$ & 36 & - & - & - & - & - & - & - & - & 7 & - & 17 & - & $1 / 7$ & $4 / 7$ \\
\hline & $\mathrm{OG}^{3}$ & 68 & - & - & - & - & - & - & - & - & 25 & - & 33 & - & $3 / 24$ & $7 / 24$ \\
\hline Bautista et al. (29) & $Y G$ & 46 & - & - & - & - & - & - & - & 31 & - & - & - & - & - & - \\
\hline & $O G$ & 1,208 & - & - & - & - & - & - & - & 475 & - & - & - & - & - & - \\
\hline Wang et al. (30) & $Y G$ & 342 & - & - & 327 & 15 & - & - & - & 267 & - & - & - & - & 16 & 13 \\
\hline & OG & 3,588 & - & - & 3,406 & 182 & - & - & - & 2,856 & - & - & - & - & 165 & 173 \\
\hline
\end{tabular}

No., number of patients; YG, younger group; OG, older group; R, resection margin. 